\title{
FSH for the Treatment of Male Infertility
}

\author{
Livio Casarini ${ }^{1,2, *}$, Pascale Crépieux ${ }^{3}$, Eric Reiter ${ }^{3}$, Clara Lazzaretti ${ }^{1,4}$, Elia Paradiso ${ }^{1,4}$, \\ Vincenzo Rochira $^{1,5}$, Giulia Brigante ${ }^{1,5}{ }^{-}$, Daniele Santi ${ }^{1,5}{ }^{-}$and Manuela Simoni ${ }^{1,2,3,5}$
}

1 Unit of Endocrinology, Department of Biomedical, Metabolic and Neural Sciences, University of Modena and Reggio Emilia, Via P. Giardini 1355, 41126 Modena, Italy; clara.lazzaretti@unimore.it (C.L.); elia.paradiso@unimore.it (E.P.); vincenzo.rochira@unimore.it (V.R.); giulia.brigante@unimore.it (G.B.); daniele.santi@unimore.it (D.S.); manuela.simoni@unimore.it (M.S.)

2 Center for Genomic Research, University of Modena and Reggio Emilia, Via G. Campi 287, 41125 Modena, Italy

3 Physiologie de la Reproduction et des Comportements (PRC), Institut National de Recherche pour l'Agriculture, l'Alimentation et l'Environnement (INRAE), Centre National de la Recherche Scientifique (CNRS), Institut Français du Cheval et de l'Equitation (IFCE), Université de Tours, 37380 Nouzilly, France; pascale.crepieux@inrae.fr (P.C.); eric.reiter@inrae.fr (E.R.)

4 International PhD School in Clinical and Experimental Medicine (CEM), University of Modena and Reggio Emilia, Via G. Campi 287, 41125 Modena, Italy

5 Unit of Endocrinology, Department of Medical Specialties, Azienda Ospedaliero-Universitaria, Via P. Giardini 1355, 41126 Modena, Italy

* Correspondence: livio.casarini@unimore.it; Tel.: +39-0593961705; Fax: +39-0593962018

Received: 2 March 2020; Accepted: 24 March 2020; Published: 25 March 2020

\begin{abstract}
Follicle-stimulating hormone (FSH) supports spermatogenesis acting via its receptor (FSHR), which activates trophic effects in gonadal Sertoli cells. These pathways are targeted by hormonal drugs used for clinical treatment of infertile men, mainly belonging to sub-groups defined as hypogonadotropic hypogonadism or idiopathic infertility. While, in the first case, fertility may be efficiently restored by specific treatments, such as pulsatile gonadotropin releasing hormone (GnRH) or choriogonadotropin (hCG) alone or in combination with FSH, less is known about the efficacy of FSH in supporting the treatment of male idiopathic infertility. This review focuses on the role of FSH in the clinical approach to male reproduction, addressing the state-of-the-art from the little data available and discussing the pharmacological evidence. New compounds, such as allosteric ligands, dually active, chimeric gonadotropins and immunoglobulins, may represent interesting avenues for future personalized, pharmacological approaches to male infertility.
\end{abstract}

Keywords: male infertility; FSH; testis; biosimilars; gonadotropin

\section{Introduction}

Follicle-stimulating hormone (FSH) is a dimeric glycoprotein released by the pituitary and targeting gonadal cells of both males and females. The molecule is structurally similar to luteinizing hormone (LH) which, together with FSH, regulates reproduction acting through specific G protein-coupled receptors (GPCRs) and modulating steroidogenesis, cell metabolism and growth [1]. Despite similarities between these two hormone-receptor systems, gonadotropins mediate sex-specific effects mainly due to a physiologically different expression of steroidogenic enzymes and receptors, according to different cell types. In particular, in the steroidogenic ovarian granulosa cell, the FSH receptor (FSHR) is co-expressed with the LH (and choriogonadotropin, hCG) receptor (LHCGR) during the fertile age, while only the FSHR is expressed in the non-steroidogenic Sertoli cells, in the testes. Therefore, the nature of FSH action is different in the two genders, hence the clinical approaches to infertility [2]. To 
this purpose, a number of strategies and hormonal drugs were developed and used for the treatment of infertile women, while more efforts are necessary for optimizing therapy for male infertility [3]. In this review, we discuss the action of FSH, as well as its current use and perspectives for treating male infertility.

\section{FSH-Induced Signaling Network}

FSH binding to its cognate receptor, the FSHR, leads to the rewiring of a complex intracellular signaling network that profoundly alters gene regulation at several levels. Hormone binding to the Leucine-rich repeat domain provokes conformational changes in the receptor, including the interaction of a sulfated tyrosine within the receptor hinge region with the interface of FSH $\alpha$ and $\beta$ chains $[4,5]$, and tethering of a decapeptide that protrudes out of the plasma membrane from the first intracellular transmembrane helix [6]. Work is still ongoing to decipher the crystal structure of the entire FSHR, including transmembrane domains, in active conformation. It is likely that these changes propagate to the transmembrane helices, leading to $G \alpha$ s protein activation, in agreement with the activation mechanisms depicted for other G $\alpha$ s-coupled GPCRs such as the $\beta 2$-adrenergic receptor [7-9]. The FSHR is also rapidly desensitized upon phosphorylation by GPCR kinases (GRKs), that create anchoring sites for $\beta$-arrestins [10-16]. These scaffolding proteins initiate internalization of desensitized GPCRs by binding to clathrin-coated pit components such as the adaptor protein complex (AP2) [17].

A prominent effector of $\mathrm{G} \alpha$ s protein-coupled FSHR is adenylate cyclase, that catalyzes the cyclization of adenosine monophosphate (AMP) to cyclic AMP (cAMP), and ultimately regulates the activity of its intracellular targets, mainly protein kinase A (PKA) and, presumably, exchange factors directly activated by cAMP (EPAC). However, the FSH signal is transduced via proteins other than the canonical $\mathrm{G} \alpha \mathrm{s}$, as demonstrated initially by adenovirus-mediated expression of a constitutively active form of $\mathrm{G} \alpha$ s protein, G $\alpha \mathrm{s}$ Q227L, in granulosa cells [18]. In this condition, ligand-independent cAMP production enhanced progesterone secretion to a level comparable to $\mathrm{FSH}$, but estradiol production was decreased. In fact, these data are indicative of the link between the G $\alpha$ s protein/cAMP/PKA-pathway to steroidogenesis, the latter being absent in Sertoli cells. Studies in primates revealed that FSH would act synergistically with testosterone $(\mathrm{T})$ in priming the Sertoli cell response to endogenous stimuli that sustain spermatogenesis $[19,20]$, indicating that the FSH-induced cAMP/PKA-pathway exerts a trophic [21], rather than steroidogenic function, which is committed to LH [22]. Moreover, pleiotropic coupling of the FSHR to other G proteins has been demonstrated [23]: for example, coupling of the FSHR to the Gai protein is critically involved in Sertoli cell proliferation in the neonate rat [24]. In addition, LH-induced coupling of the LHCGR to G $\alpha$ q is rearranged when the FSHR is co-expressed in the same cell, as occurs during follicular growth. However, the cross-talk between FSHR- and LHCGR-mediated signal transduction pathways in the same cell is absent in males, where these receptors are specifically expressed in Sertoli and Leydig cells, respectively, located apart from each other.

Beside their ability to promote desensitization and internalization, $\beta$-arrestins also assemble a plethora of signaling modules, as shown for many different GPCRs $[25,26]$. So far, however, upon FSHR stimulation, only the extracellular-regulated (ERK) mitogen-activated protein (MAP) kinase- and ribosomal protein 66 kinase beta-1 (p70S6K)-dependent signaling has been demonstrated to be partly mediated by $\beta$-arrestins. Of note, when comparing the mode of activation of both of these pathways in HEK293 cells, ERKs are activated sequentially through $G \alpha$ s and $\beta$-arrestins [16], whereas the p70S6K pathway is activated concomitantly by these two transducing mechanisms [27]. This observation emphasizes the role of GPCR transducers to coordinate the dynamics of the downstream signaling network and has potential implications regarding the action of FSHR biased ligands described in the next sub-sections of this review.

Both of these signaling pathways exhibit developmental regulation [24,28]. For example, ERK MAP kinases mediate the mitotic function of FSH in neonatal Sertoli cells [24] and in immature granulosa cells [29], by increasing the expression of D1 and D2 cyclins, respectively [24,30]. In both FSH natural target cells, ERK activation is at least cAMP-dependent, and it is not known whether $\beta$-arrestins 
intervene. Interestingly, $\beta$-arrestins appear to be involved in cell survival, that is accompanied by ERK phosphorylation, as observed in the immortalized human granulosa cell line hGL5 [31].

As for the p70S6K pathway, the role of $\beta$-arrestins in its activation in seminiferous tubules or in follicles has not been clarified yet, although in Sertoli cells, $\beta$-arrestin 1 and p70S6K can be identified in common protein complexes [27]. p70S6K activation relies on protein kinase B (Akt) [28,32], and activation of this pathway is presumably responsible for enhancing mRNA translation measured in response to FSH [33,34], as a hallmark of FSH anabolic function and trophic role. Interestingly, FSH-activated Akt appears to protect cells from autophagy, by inhibiting the transcription factor forkhead box protein O1 (FOXO1) and promoting its nuclear exclusion. By these means, FOXO1 can no longer stimulate the expression of autophagy-related genes [35]. FOXO1 is key to the differentiating action of FSH, at least in granulosa cells and, quite unexpectedly, a recent genome-wide analysis revealed that most FSH-responsive genes had FOXO1-binding sites in their promoter $(60 \%$ of identified genes), and not CREB-binding elements (CRE), as anticipated [36]. While FOXO1 is constitutively nuclear and bound to DNA, where, for example, it inhibits the expression of proliferation genes such as Cyclin D2 [37], these data suggest that the role of FSH would be to counteract the general action of this transcription factor. This echoes the fact that Akt likely antagonizes the pro-apoptotic role of cAMP, that otherwise has no effect on FOXO1.

Ultimately, the FSH-regulated signaling network alters the gene expression pattern of gonadal cells. The influence of FSH-induced signaling on gene expression, however, extends far beyond the regulation of mRNA transcription and translation, and microRNAs (miRNAs) now appear as key players in the control of reproductive function. Accordingly, Dicer, a key enzyme of miRNA processing, is involved in the expression of genes essential for meiosis and spermiogenesis, as demonstrated by Sertoli cell-selective knock-out in mouse of the Dicer gene [38]. By similar experiments, the importance of Dicer in ovulation has also been stressed in vivo [39-41], and the expression of several miRNAs leading to key regulators of follicular growth is sensitive to FSH. For example, FSH inhibits the expression of the miR10 family, otherwise involved in a pro-apoptotic negative feedback loop of transforming growth factor beta (TGF $\beta$ ) activity [42]. In the male rat where FSH and testosterone action was suppressed, the miRNA network was identified at spermiation, a spermatogenesis stage particularly sensitive to hormone regulation. At this stage, elongated spermatids are released from Sertoli cells, a process accompanied by complex membrane rearrangements. Four miRNAs of this microarray analysis appeared complementary to the phosphatase and tensin homolog (PTEN) mRNA, that were localized in the apical region of Sertoli cells, in the vicinity of mature spermatids. The hormonal input would lead to the degradation or synthesis inhibition of these miRNAs, then stabilizing PTEN at spermiogenesis [43]. Interestingly, the PTEN protein level is increased following FSH cell stimulation in vitro, leading Sertoli cells to achieve terminal differentiation [44]. Since FSH enhances PTEN protein level within minutes, the mechanisms involved probably occur post-transcriptionally, similarly to the hormone-induced degradation of miRNA that prevents the accumulation of PTEN locally in Sertoli cells at spermiation. Hence, miRNA networks might regulate the compartmentalization of FSH signaling components in Sertoli cells and control the kinetics of these biochemical reactions. These examples point to a widespread role of a miRNA network that is counterbalanced by FSH function in both granulosa and Sertoli cells.

In summary, FSH mediates the activation of a complex network of signaling pathways (Figure 1), in gonadal target cells, that is not completely deciphered yet. In the context of female fertility, several studies attempted to determine congenital and environmental issues modulating the response to FSH $[45,46]$, aiming to improve assisted reproductive technologies (ART) outcomes [47]. In the male, deficiency of FSH signaling may impair fertility and requires clinical treatments for restoring the gonadal function [48]. For these purposes, a number of FSH molecules were developed to modulate the target cell response to the hormone and used for infertility treatments. 


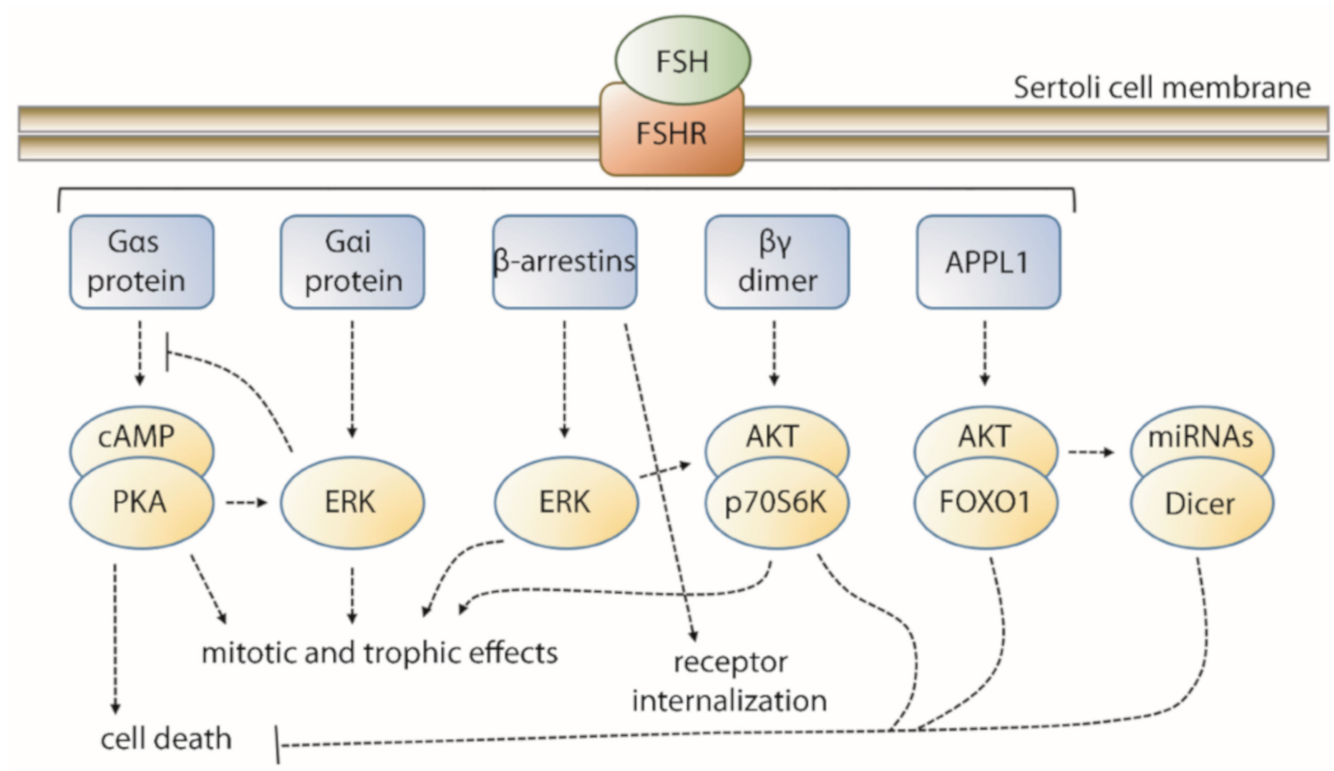

Figure 1. Main follicle-stimulating hormone (FSH)-mediated signaling network in Sertoli cells. Intracellular FSH receptor (FSHR) interactors are indicated in blue and associated with the downstream signaling modules. Most of the signaling cascades culminate with mitotic and trophic effects in Sertoli cells, while other signals are addressed to anti-apoptotic effects and $\beta$-arrestin-mediated FSHR internalization.

\section{FSH in Therapy}

The employment of FSH for infertility treatments started in the early 1960s, when the first gonadotropic compound was extracted from human pituitary glands. For a long time after that, urinary-derived and highly-purified hormones have been used, in spite of supply problems and the risk of diseases due to potential contamination with prions [49], until the advent of recombinant FSH [50]. Currently, several recombinant and biosimilar FSH molecules are marketed, along with highly purified urinary FSH preparations. Biosimilars were developed after the patent of follitropin alpha and beta expired, and have a similar, albeit not identical molecular structure, and the same biological action as the originator [51]. The therapeutic employment of all these FSH preparations is mainly in the context of female infertility and assisted reproduction, while its use in the male is limited to hypogonadotropic hypogonadism [3]. FSH therapy in male idiopathic infertility is currently discussed [3] but no convincing evidence of its efficacy exists.

Human FSH is composed by an $\alpha$ subunit, common to all glycoprotein hormones, and a hormone-specific $\beta$ subunit, which both undergo important post-translational changes. In fact, FSH is secreted by the pituitary as a mixture of different glycosylated variants [51-54], which differ in the number and the composition of oligosaccharides attached to the protein, resulting in changes in the molecule half-life and isoelectric point [55]. Two of the four N-glycosylation sites are located on the $\alpha$ chain at positions 52 and $78\left(\mathrm{Asn}^{52}\right.$ and $\left.\mathrm{Asn}^{78}\right)$, whereas the two others, linked to the asparagine at positions seven and 24 are located on the $\beta$ subunit $[53,56]$. Four main $\mathrm{FSH} \beta$-specific glycoforms exist: a fully glycosylated form, indicated as $\mathrm{hFSH}^{24}$, the forms $\mathrm{hFSH}^{21}$ and $\mathrm{hFSH}^{18}$, carrying glycosylations at the $\mathrm{Asn}^{7}$ and $\mathrm{Asn}^{24}$, respectively, and the $\mathrm{hFSH}^{15}$, lacking glycosylations on the $\beta$ subunit [54]. The degree of sialylation and antennarity of the oligosaccharide chain can deeply influence the hormonal bioactivity $[54,57,58]$. Variations in serum levels of FSH glycoforms were found and suggest that they might have different physiological activity in men, where FSH isoform composition is demonstrated to change with age [51,59].

The rationale supporting the glycoform-specific activity relies on the assumption that different oligosaccharide chains may modulate the hormone-receptor structural interaction $[58,60,61]$ and the downstream signaling cascades $[57,58,62]$. These considerations generated the idea that FSH variants 
could act as biased receptor agonists [63] and the impact of carbohydrate heterogeneity on FSH bioactivity was investigated both in vitro and in vivo [57,58]. For instance, a study showed that the hypo-glycosylated forms of $\mathrm{FSH}\left(\mathrm{hFSH}^{21} / \mathrm{hFSH}^{18}\right)$ exhibit a greater receptor binding activity compared to the fully glycosylated molecule in vitro [64]. However, in vivo studies have only partially confirmed what was found in vitro; female FSH $\beta$-encoding gene (FSHB) null mice injected with different doses of $\mathrm{hFSH}^{21} / \mathrm{hFSH}^{18}$ or $\mathrm{hFSH}^{24}$ had higher estradiol production with less glycosylated forms. These two glycoforms also impact on specific subsets of FSH-responsive genes, but no different activation of PKA, CREB, p38 MAPK, ERK and AKT were found, as well as ovarian weight gain, between less and fully glycosylated FSH $[65,66]$. These experiments suggest that the biased activity of FSH variants observed in vitro is likely attenuated in vivo. Interestingly, different data emerged from male FSHB null mice, where $\mathrm{hFSH}^{21} / \mathrm{hFSH}^{18}$ promoted the increase of testicular weight more efficiently than the fully glycosylated $\mathrm{FSH}^{24}$, correlating with testis tubule size and the number of germ cells per tubule. In Sertoli cells of these animals, less glycosylated FSH promoted significantly higher expression levels of target genes and activation of proliferation markers than $\mathrm{hFSH}^{24}$ [65]. Taken together, these data are suggestive of a relevant physiological impact of FSH glycoforms, even though this impact is likely to be sex-specific.

During the last decades, the knowledge about FSH glycosylation was exploited for the development of new molecules for improving infertility treatments of both males and females [51,52,59]. Recombinant FSH is obtained from cultured mammalian cells and has a better safety, purity, specific activity, and batch-to-batch consistency than the urinary molecule [49]. Even if superiority of the recombinant hormone was claimed in the context of ovarian stimulation [67], the literature on this topic would require further, independent investigations and should be considered cautiously. In any case, isoform composition is different between recombinant and urinary FSH. The recombinant hormone contains a higher proportion of less-acidic isoforms, while human urinary FSH includes higher number of acidic forms. The less-acidic isoforms present a shorter circulatory half-life because they have a faster circulatory clearance than the acidic isoforms [68]. On the other hand, the acidic isoforms have relatively slow clearance, and induce better follicular maturation and estradiol secretion, than the less-acidic isoforms [69]. More acidic FSH isoforms have a prolonged half-life due to reduced kidney clearance and are secreted during the early and mid-follicular phase $[69,70]$. Furthermore, the half-life of the gonadotropin may even be prolonged by additional glycosylation sites obtained after amino acid chain manipulation [71]. Less is known about the efficacy of these molecules in the male. A comparison between recombinant and urinary FSHs was performed in men affected by congenital or acquired hypogonadotropic hypogonadism (HH) [72]. In this study, patients were treated for 3 to 6 months with hCG before the addition of daily FSH injection for 18 more months, resulting in beneficial effects evaluated as testis growth, spermatogenesis and fertility restoration. This study revealed no difference between the urinary and recombinant hormones [72].

To date, there are three marketed recombinant non-chimeric FSHs: follitropin alpha and follitropin beta, both expressed in the Chinese Hamster Ovary $(\mathrm{CHO})$ cell line, and the recently developed follitropin delta expressed in the human fetal retinal cells PER.C6 [73]. These molecules have the same amino acid sequence but differ in glycosylation, composition of sialic acid residues and isoelectric coefficients [74]. Follitropin alpha is more acidic than follitropin beta, resulting in different biological activity, half-life and metabolic clearance [75]. Moreover, follitropin alpha has only alphan ${ }^{2,3}$-linked sialic acid, while follitropin delta includes a higher proportion of tri- and tetra-sialylated glycans, with both alpha ${ }^{2,3}$ - and alpha ${ }^{2,6}$-linked sialic acid [76]. Another FSH molecule is under testing; it is called follitropin epsilon and is claimed to have optimized human glycosylation, with pharmacokinetics [77] and overall ovarian response similar to follitropin alpha [78].

A number of FSH biosimilars are under evaluation and have not yet passed the clinical phase III/preclinical testing (Table 1), while Gonapure ${ }^{\circledR}$ (Minapharm Pharmaceuticals, Cairo, Egypt), DA-3801 ${ }^{\circledR}$ (Dong-A ST/Genexine, Seoul, South Korea) and Cinnal-F ${ }^{\circledR}$ (CinnaGen, Tehran, Iran) were marketed recently and only in their countries of origin. Therefore, the number of independent 
studies comparing their performances to those of the originator are too low to be fully informative. Instead, the two follitropin alpha biosimilars marketed as Ovaleap ${ }^{\circledR}$ (Theramex Ireland Limited, Dublin, Ireland) and Bemfola ${ }^{\circledR}$ (Gedeon Richter, Budapest, Hungary) were compared to the reference product Gonal-f ${ }^{\circledR}$ (Merck KGaA, Darmstadt, Germany), having different structures due to post-translational modifications $[53,79]$. In fact, in vitro data indicated that they would modulate a similar pattern of intracellular signaling activation and steroid synthesis, in FSHR-expressing cells, although the measurement of calcium ions $\left(\mathrm{Ca}^{2+}\right)$ increased suggesting that these hormones may act as biased ligands [79]. Similar results were obtained by comparing follitropin alpha and follitropin delta in vitro, showing similar binding affinity and potency in the activation of FSHR-mediated cAMP increase and steroid synthesis, in transfected HEK293 and human primary granulosa cells, respectively [80]. However, in rodents, the injection of these FSH isoforms exhibited different pharmacokinetics, due to the clearance operated by different metabolic pathways, depending on the type of glycan linked to the hormones [80].

Table 1. FSH originator and biosimilars.

\begin{tabular}{|c|c|c|}
\hline Drug Name & Status & Originator \\
\hline GONAL-f & Marketed & Merck \\
\hline Cinnal-f & Marketed & CinnaGen \\
\hline DA-3801 & Marketed & Dong-A Pharmaceutical \\
\hline Bemfola & Marketed & Gedeon Richter \\
\hline Ovaleap & Marketed & Theramex \\
\hline Gonapure & Marketed & Minapharm Pharmaceuticals \\
\hline $\begin{array}{c}\text { Follitropin alpha } \\
\text { biosimilar-Allergan/Itero } \\
\text { Biopharmaceuticals }\end{array}$ & Phase III & Itero Biopharmaceuticals \\
\hline LM-001 & Preclinical & Alphamab \\
\hline $\begin{array}{c}\text { Follitropin alpha } \\
\text { biosimilar-Cadila Healthcare }\end{array}$ & Phase III & Cadila Healthcare \\
\hline Folitime & No development reported & GEMA \\
\hline Primapur & Phase III & iVFarma \\
\hline ProLease & Discontinued & Merck Serono \\
\hline
\end{tabular}

Data source: AdisInsight database-Springer. Available online at: https://adisinsight.springer.com (accessed on 1 March 2020).

To overcome the relatively short half-life of FSH, which requires daily administration, a new recombinant molecule with a prolonged action was produced in transfected CHO cells [81], corifollitropin alpha (Elonva ${ }^{\circledR} ;$ MSD, Readington, NJ, USA). This chimeric molecule includes the sequence encoding the CTP extension of hCG $\beta$ fused to the human FSH $\beta$ subunit, which bears four O-linked glycosylation sites and provides extended half-life $[82,83]$. Corifollitropin alpha has slower absorption and longer elimination half-time than follitropin alpha [84] so that one single injection can replace seven daily injections of follitropin alpha [85-87]. In fact, in cultured primary human granulosa cells, corifollitropin was demonstrated to be more potent than FSH in increasing aromatase gene expression [88], suggesting a high capability of inducing estrogen synthesis. This finding supports in vivo observations reporting that women treated with corifollitropin alpha have a higher number of metaphase II oocytes at ovum pick-up and of formed embryos, as well as higher overstimulation risk compared to FSH (parameters are highly dependent on the estrogenic functions but require further examinations in vivo) [89].

In summary, we can assume an overall clinical equivalence of various recombinant FSH molecules available. This equivalence is evident in vitro, especially when they are compared in cell systems expressing both FSHR and LHCGR, such as the human granulosa cells, and in vivo in clinical, non-inferiority studies. While, in the first case, FSH-induced signals may be modulated through the molecular cooperation of the two receptors $[90,91]$ that attenuates the glycoform-specific activation of downstream signaling cascades [92], data obtained in vivo may be affected by the complex 
network of hormone actions and by the genetic background of the host, impeding a proper dissection of the hormone-specific effects. Most of the results demonstrating specific biological effects of FSH iso/glycoforms were obtained in cell models expressing only the FSHR and lacking LHCGR expression [64,79]. Therefore, these data are suggestive of hormone-specific activity in Sertoli cells, since expressing only the FSHR indicates a potential way for personalizing treatments of infertile male patients.

\section{FSH Use in Hypogonadotropic Hypogonadism: State-Of-The-Art}

Male infertility is a multifactorial clinical condition affecting at least half of infertile couples. Within the long list of known pathogenic causes of male infertility, $\mathrm{HH}$ may represent at least $10 \%$ of cases in highly specialized centers [93-95]. In this disease, a congenital or acquired defect of hypothalamic gonadotropin releasing hormone $(\mathrm{GnRH})$ production/function and/or pituitary gonadotropin secretion is observed, leading to impaired testicular functions [93-95]. On the other hand, 30-40\% of male infertility cases remain idiopathic, without a detectable pathogenesis characterized by abnormal semen parameters [96]. Whereas a specific and efficient treatment to restore fertility exists for $\mathrm{HH}$ patients, in male idiopathic infertility only empirical approaches are available.

In central $\mathrm{HH}$, fertility can be restored using either GnRH or exogenous gonadotropins. Pulsatile GnRH administration represents, conceptually, the best replacement therapy, leading to the secretion of endogenous gonadotropins from the pituitary gland and the consequent stimulation of physiological testicular functioning, inducing intra-testicular testosterone production and Sertoli cell support [97-100]. However, this therapeutic approach is not routinely used, since it requires an external pump delivering GnRH pulses subcutaneously, with high costs and discomfort for the patient. On the other hand, the administration of exogenous gonadotropins may be a successful treatment in most cases. In particular, testosterone-mediated virilization and sperm production may be efficiently restored by hCG alone or administered together with FSH, although the optimal scheme, timing and dosage for this treatment remains controversial. Indeed, the issue is debated and was recently evaluated by a meta-analysis assessing the effects of hCG alone or in combination with FSH, administered in a variety of clinical settings, on sperm concentration of $\mathrm{HH}$ subjects [101]. Gonadotropin stimulation was beneficial in $75 \%$ of the cases, which obtained a final mean sperm concentration of $5.92 \mathrm{million} / \mathrm{mL}$ [101], sufficient to obtain a pregnancy, although sub-physiological [102]. These data suggest the existence of a beneficial, synergistic action of FSH and hCG-induced testosterone, restoring fertility despite sub-optimal sperm parameters [101]. However, clinical trials evaluating the effects of gonadotropins in inducing fertility in HH have some limitations. The therapy relies on the administration of exogenous gonadotropins, which does not replace the pulsatile pituitary secretion fundamental for delivering a physiological signal naturally regulating fertility in mammals [103], even if this approach seems to be as efficient as pulsatile GnRH therapy [101]. Most studies using gonadotropins were based on hCG, instead of the physiological hormone LH, which was present in the old hMG preparations but is absent from the modern, highly purified urinary gonadotropins. In light of the different intracellular signaling pattern mediated by LH and hCG [83] in Leydig cells [104,105], and considering that hCG has no functions in the adult male, where androgen production is supported by LH action, hCG might not be the optimal therapy and this possibility should be verified in future studies. In any case, intratesticular testosterone plays a central role in sustaining spermatogenesis, and this can be induced through the steroidogenic action of hCG, while FSH contribution would be mainly supportive of sperm quality $[106,107]$.

\section{FSH Use in Idiopathic Infertility: State-Of-The-Art}

Many cases of male infertility remain idiopathic, revealing the current inability to define the underlying causes. In these cases, a rational pharmacological treatment does not exist, and clinicians attempt to stimulate spermatogenesis with various and not univocal results. Estrogen receptor modulators (SERM), such as tamoxifen and clomiphene citrate, are used off-label in some countries for treating male infertility $[108,109]$. These drugs block the estrogen receptor alpha, reducing the 
negative feedback at the hypothalamo-pituitary level and increasing the release of FSH and LH [110]. The efficacy of SERMs in treating idiopathic male infertility, evaluated by 11 randomized trials and combined in a recent meta-analysis, indicates that these drugs may be beneficial for increasing sperm concentration, sperm motility and pregnancy rate [111]. Also FSH administration was proposed as a treatment for idiopathic infertile men with impaired semen parameters and normal FSH serum levels $[112,113]$. The rationale of this application resides in the FSH effect on spermatogenesis, although its efficacy remains controversial and difficult to prove. Moreover, this approach has the limitation of relatively high costs and off-label usage [114], so that only limited clinical data are available [112,113]. To date, seventeen clinical trials evaluated FSH use in idiopathic infertile men and were listed in an opinion article [115], obtaining different results. These data were recently meta-analyzed and suggested that the use of FSH may increase overall pregnancy rates, which, however, was never considered as the primary end point in the original studies $[116,117]$. The evidence generated by clinical trials and meta-analyses is still weak, considering the very low number of patients treated by FSH, as well as the limitations intrinsic to considering pregnancy as the primary endpoint. This parameter is potentially biased by the female factor, limiting the comprehension of FSH benefits for male idiopathic infertility $[116,117]$. Moreover, since more than 15 idiopathic infertile men must be treated to achieve at least one pregnancy [116], a clinical study with large sample size is not easily feasible and data available to date are not sufficient to recommend an extensive FSH use. Despite the low and even diverging [118] experimental evidence, European clinical guidelines suggest the treatment with FSH as potentially beneficial for quantitative and qualitative sperm parameters and pregnancy rate, in selected men with idiopathic oligozoospermia or oligoasthenoteratozoospermia [112,113].

Clinical studies in idiopathic infertile men suggested sperm production dependency on the FSH dose $[119,120]$, providing a rationale for optimizing the clinical approaches to the disease, which are currently mostly empirical. Indeed, data from the clinical studies indicated that the use of FSH would not be beneficial in about half of the patients. Clinical evaluations should be corrected for confounding factors, such as pharmacogenetic markers, which might lead to unclear results if ignored. These considerations emerged from studies in FSH-treated idiopathic infertile men, after consideration of the FSHR allelic state [106]. The FSHR carries a single nucleotide polymorphism (SNP), falling at position 680 of the receptor amino acid chain (p.N680S; rs6166), influencing testicular volume in men [121] and FSH-induced intracellular signaling in vitro [122]. Three months of daily FSH administrations improved the sperm quality of p.N680S $\mathrm{N}$ homozygous idiopathic infertile men, but not that of homozygous S [106], suggesting that the FSHR could be a pharmacogenetic marker. Other SNPs falling within genes regulating FSH-dependent signals are potential markers of sperm count and/or quality, as well as response to FSH treatment [123]. The FSHR promoter rs1394205 polymorphism is characterized by a $G$ to A nucleotide change at position -29 upstream the start codon $(-29 G>A)$, that modulates the gene transcriptional activity [124] and is associated with FSH serum levels in men $[125,126]$. Another example is provided by the rs10835638 $(-211 \mathrm{G}>\mathrm{T})$ polymorphism of the FSH $\beta$-encoding gene (FSHB) [127] influencing serum hormone levels, sperm parameters and gonadal function in different male populations [128-130]. The combinations of p.N680S and other FSHR SNPs are linked to individual-specific pathophysiological effects [126,131,132], opening perspectives for a new pharmacological approach, optimizing the pharmacogenetic potential of FSH for infertility treatments.

\section{Future Directions in the Control of FSHR Signaling}

The development of novel FSHR modulators has been pursued for years by both academia and the pharmaceutical industry. These efforts can be categorized in three main groups: small non-peptide ligands, single-chain recombinant FSH and antibodies/antibody fragments. In the meantime, the concepts about GPCR activation and pharmacology have deeply evolved. Overwhelming structural, biophysical and pharmacological evidence now supports the co-existence of multiple active and inactive receptor conformations [133-135]. Moreover, compounds displayed different relative potencies in various assays, promoting the notion that pharmacological efficacy is multi-dimensional instead of 
bi-dimensional as predicted by the two-state model of receptor activation [136,137]. This led to the notion of pharmacological bias or ligand-directed signaling, in which different ligands stabilize distinct conformation ensembles, hence distinct transduction mechanisms [138-140]. Another important development has been the advent of allosteric modulators. These are ligands that bind a GPCR at sites distinct from the one used by the endogenous ligand and can also elicit biased responses. They can affect either positive (positive allosteric modulator, PAM) or negative (negative allosteric modulator, NAM) receptor activity. Moreover, they can act alone (ago-PAM) or in conjunction with the endogenous ligands (PAM or NAM) [141,142]. Importantly, some biased ligands have been reported to increase the window between side effects and therapeutic benefits, therefore opening great opportunities in drug discovery $[143,144]$. Of course, these advances and novel opportunities also apply to the targeting of FSHR.

Small non-peptide ligands have been explored in order to control FSHR activity with the ultimate objective of developing orally active drugs. Early studies demonstrated that some thiazolidinone derivatives displayed ago-PAM, NAM or potentially biased (i.e., preferential coupling to G $\alpha$ s or G $\alpha$ i) activities at the FSHR $[145,146]$. Several thiazolidinones demonstrated efficacy in rat granulosa cells and induced folliculogenesis in vivo in immature rats. However, further developments were hampered by unfavorable pharmacokinetics parameters [147]. Benzamides also showed selective PAM activity for FSHR compared to TSHR and LHCGR [148]. Dihydropyridine Org 24444-0 increased FSH-induced FSHR activation in vitro and induced follicle maturation in vivo [149]. Despite such promising effects on FSHR-induced signaling, neither benzamides nor dihydropyridines reached the market.

Non-peptide ligands were also reported to turn off FSHR signaling. Tetrahydroquinolines showed antagonistic effects on cAMP production without impairing FSH binding but no effect was observed in vivo [150]. ADX61623 showed decreased FSHR-induced cAMP production while improving FSH binding affinity. It was also able to decrease progesterone but not estradiol production in vitro [151]. Two other compounds from the same ADX series were later reported as biased NAMs at the FSHR: ADX68692 and ADX68693. ADX68692 decreased cAMP, progesterone and estradiol production in rat granulosa cells while ADX68693 reduced cAMP and progesterone but not estradiol production in the same model. Interestingly, ADX68692 efficiently reduced the number of oocytes recovered in mature female rats whereas the ADX68693 did not [152]. These two compounds also had biased NAM activities on LHCGR signaling [153] and suggest the opportunity to control the human reproduction with non-steroidal, pharmacological contraceptives.

Another line of research has been centered on the development of single-chain gonadotropins [154]. Initial success obtained with single-chain recombinant hCG (hCG $\beta$-subunit fused to the N-terminus of the gonadotropin $\alpha$-subunit) led to the development of single-chain analogues of FSH [155]. In addition to the FSH-CTP, some analogues presenting dual FSH and LH activities were recently developed. Single chain FSH was engineered using the hCG $\beta$ CTP as a linker between FSH $\beta$-subunits and the $\alpha$-subunit. These analogues had comparable or improved biological activity in vivo compared to native FSH, half-lives were also improved presumably because O-linked glycosylation sites of the CTP reduced hepatic clearance rates [156-158]. Some analogues (Figure 2) presenting dual FSH and LH activities (FSH $\beta$-CTP-CG $\beta-\alpha$ and FSH $\beta$-CTP-LH $\beta-C T P-\alpha$ ) increased serum estradiol, ovarian weight and the formation of corpora lutea when injected in sheep [158-160]. To date, no single-chain FSH or dually active gonadotropin analogue has reached the clinical phase of development. 
A

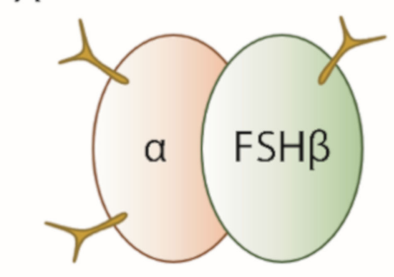

B

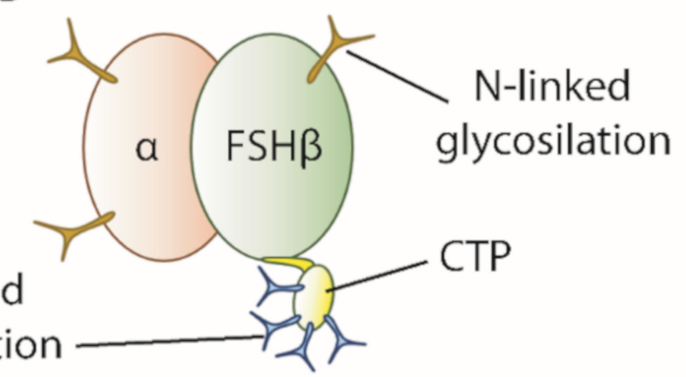

C

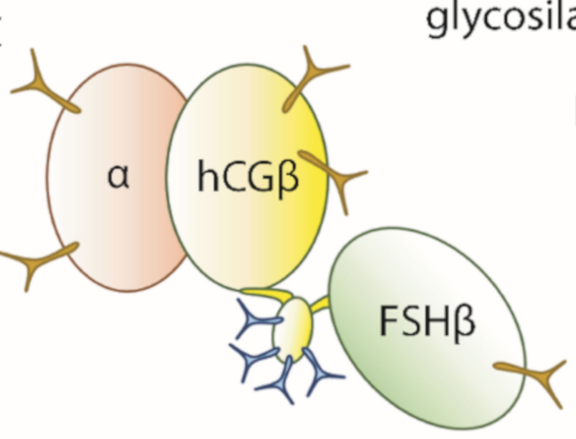

O-linked

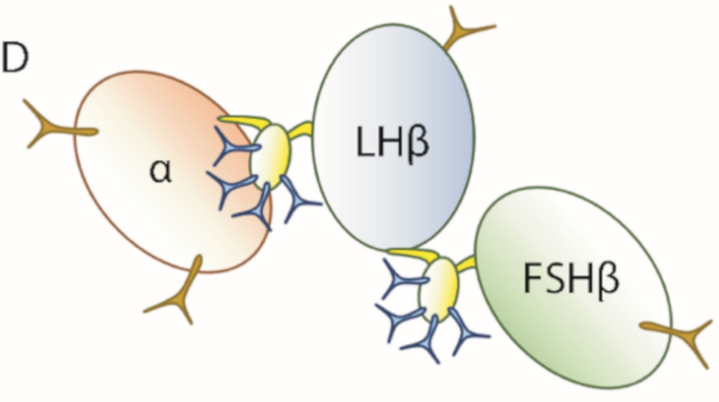

Figure 2. Schematic representation of FSH, FSH-CTP, and of the FSH $\beta-C T P-C G \beta-\alpha$ and FSH $\beta-C T P-L H \beta-C T P-\alpha$ analogues; (A) FSH molecule; (B) FSH-CTP with four additional O-linked glycosylations; (C) dually active FSH $\beta$-CTP-CG $\beta-\alpha$ analogue. (D) dually active FSH $\beta$-CTP-LH $\beta-C T P-\alpha$ analogue.

Antibodies and antibody fragments targeting GPCRs currently receive a lot of interest, culminating with two anti-GPCR therapeutic antibodies recently approved [161-163]. The idea that antibodies also represent a potential alternative to develop modulators of FSHR signaling is supported by the literature. In fact, antibodies raised against the $\beta$-subunit of bovine or ovine FSH potentiated the biological activity of FSH in mice $[164,165]$. Equine chorionic gonadotropin (eCG) shows natural interspecies promiscuity since it can bind to FSHR and LHCGR and modulate the signaling in non-equine species and for this reason, it has been widely used to control reproduction in farm animals [166-168]. Anti-eCG antibodies/eCG complexes were collected from the serum of goats treated with eCG and were shown to either stimulate or inhibit LH and FSH bioactivities depending on the animal treated [169]. Interestingly, anti-eCG/eCG complexes from three animals displayed stimulatory bioactivities. They were purified and in vitro characterized. A robust increase in ERK phosphorylation was measured when compared to eCG alone. Moreover, two of the complexes induced both PKA- and $\beta$-arrestin-dependent signaling, while the third complex stimulated only PKA-dependent signaling [170]. This demonstrates not only that anti-hormone antibodies can modulate FSH activity, but also that this modulation can be biased. Anti-FSHR antibodies and antibody fragments have been also used to control FSHR activity. A polyclonal antibody directed against the hinge-region of FSHR displayed agonistic activity, confirming the central role of the hinge region in the FSHR activation [171]. More recently, a library of synthetic nanobodies has been screened against whole cells expressing the FSHR, and anti-FSHR nanobodies were identified and behaved as non-competitive antagonists on FSHR-mediated cAMP production [172].

Interestingly, a fusion protein consisting of $\beta$-subunits fused to immunoglobulin Fc fragments was co-expressed with FSH $\alpha$. Female rats injected with this FSH-Fc analogue displayed significantly increased ovarian weight compared to FSH-treated animals, suggesting that this analogue exhibits similar advantageous pharmacokinetic properties as immunoglobulins [173].

Two other classes of pharmacological modulators, pepducins [174] and aptamers [175] have recently shown promise as GPCR modulators. Even though, to our knowledge, they have not been assessed yet in the context of FSHR targeting, they may represent interesting avenues for future developments. 


\section{Future Clinical Perspectives}

The fervor of basic research in studying new gonadotropin formulations and receptor modulators gives hope for the future. From a clinical point of view, it is necessary to improve therapy manageability and, before that, to understand the real efficacy of gonadotropins in male idiopathic infertility.

First of all, the proper use of FSH must be clarified. It is necessary to definitively determine whether the treatment with FSH improves reproductive parameters in males with serum FSH levels in the normal range. This must be done with studies on samples larger than those available so far, in order to define which therapeutic scheme is more effective. Further studies are needed to clarify optimal scheme, timing and dosage, in light of the FSHR and FSHB genetic background and developing patient-specific pharmacogenetic approaches.

An aspect still to be explored is the use of LH instead of hCG, in association or not with FSH. Since LH and hCG are different, and not fully interchangeable in their signal transduction properties, the use of LH in the treatment of male idiopathic infertility should be tested and could provide interesting results. Firstly, pharmacodynamics and the safety profile of LH in men must be assessed. Then, we should explore whether LH supplementation is able to improve spermatogenesis and pregnancy rates in infertile men over FSH alone or with FSH in association to hCG. The short half-life of LH should not be a hindrance in this case, since an increased systemic androgenization is not expected, but rather a trophic effect on Leydig cells and intratesticular testosterone is anticipated.

When the best possible scheme of association between FSH and hCG or LH is defined, it will then be necessary to produce more manageable formulations than those available today. Current therapeutic schemes are based on recurring intramuscular injections. Obviously, these modalities are invasive and need to be overcome. For this reason, new orally active drugs, e.g., small non-peptide ligands, must be studied and perfected.

New insights for achieving personalized non-hormonal approaches to male infertility may be provided by modulating the impact of immune cells on fertility. For instance, it was reported that leukocytes may entangle with sperms, reducing sperm motility and the chances of fertilization [176]. All these ideas must be aimed at finding the best treatment for all types of male infertility (potentially including the idiopathic cases) and personalizing the therapy from subject to subject, reaching the best results together with the least possible invasiveness.

Author Contributions: Conceptualization, P.C., E.R., M.S. and L.C.; Resources P.C., E.R., V.R., G.B., D.S., M.S. and L.C.; Writing-Original Draft Preparation, P.C., E.R., C.L., E.P., G.B., D.S. and L.C.; Writing-Review and Editing, P.C., E.P., V.R., G.B., D.S., M.S. and L.C.; Visualization, L.C.; Supervision, P.C., E.R., M.S. and L.C.; Project Administration, M.S. and L.C.; Funding Acquisition, P.C., E.R., V.R., G.B., D.S., M.S. and L.C. All authors listed have approved the submitted version, agree to be personally accountable for the author's own contributions and for ensuring that questions related to the accuracy or integrity of the study are appropriately investigated, resolved, and documented in the literature. All authors have read and agreed to the published version of the manuscript.

Funding: This research was funded by European Union's Skłodowska-Curie grant No 665790.

Acknowledgments: This study was supported by the Italian Ministry of University and Research by the "Departments of Excellence Programme" granted to the Department of Biomedical, Metabolic and Neural Sciences (University of Modena and Reggio Emilia (Italy). Manuela Simoni, is a LE STUDIUM RESEARCH FELLOW, Loire Valley Institute for Advanced Studies, Orléans and Tours, France, INRAE Centre Val de Loire, 37380 Nouzilly, France, receiving funding from the European Union's Horizon 2020 research and innovation programme under the Marie Skłodowska-Curie grant agreement No 665790.

Conflicts of Interest: The authors declare no conflict of interest.

\section{References}

1. Simoni, M.; Gromoll, J.; Nieschlag, E. The Follicle-Stimulating Hormone Receptor: Biochemistry, Molecular Biology, Physiology, and Pathophysiology. Endocr. Rev. 1997, 18, 739-773. [CrossRef]

2. Santi, D.; Potì, F.; Simoni, M.; Casarini, L. Pharmacogenetics of G-protein-coupled receptors variants: FSH receptor and infertility treatment. Best Pract. Res. Clin. Endocrinol. Metab. 2018, 32, 189-200. [CrossRef] [PubMed] 
3. Behre, H.M. Clinical Use of FSH in Male Infertility. Front. Endocrinol. (Lausanne) 2019, 10, 322. [CrossRef] [PubMed]

4. Jiang, X.; Fischer, D.; Chen, X.; McKenna, S.D.; Liu, H.; Sriraman, V.; Yu, H.N.; Goutopoulos, A.; Arkinstall, S.; $\mathrm{He}, \mathrm{X}$. Evidence for Follicle-stimulating Hormone Receptor as a Functional Trimer. J. Biol. Chem. 2014, 289, 14273-14282. [CrossRef] [PubMed]

5. Jiang, X.; Liu, H.; Chen, X.; Chen, P.-H.; Fischer, D.; Sriraman, V.; Yu, H.N.; Arkinstall, S.; He, X. Structure of follicle-stimulating hormone in complex with the entire ectodomain of its receptor. Proc. Natl. Acad. Sci. USA 2012, 109, 12491-12496. [CrossRef]

6. Brüser, A.; Schulz, A.; Rothemund, S.; Ricken, A.; Calebiro, D.; Kleinau, G.; Schöneberg, T. The Activation Mechanism of Glycoprotein Hormone Receptors with Implications in the Cause and Therapy of Endocrine Diseases. J. Biol. Chem. 2016, 291, 508-520. [CrossRef]

7. Rasmussen, S.G.F.; Choi, H.-J.; Fung, J.J.; Pardon, E.; Casarosa, P.; Chae, P.S.; Devree, B.T.; Rosenbaum, D.M.; Thian, F.S.; Kobilka, T.S.; et al. Structure of a nanobody-stabilized active state of the $\beta(2)$ adrenoceptor. Nature 2011, 469, 175-180. [CrossRef]

8. Rosenbaum, D.M.; Zhang, C.; Lyons, J.A.; Holl, R.; Aragao, D.; Arlow, D.H.; Rasmussen, S.G.F.; Choi, H.-J.; Devree, B.T.; Sunahara, R.K.; et al. Structure and function of an irreversible agonist- $\beta(2)$ adrenoceptor complex. Nature 2011, 469, 236-240. [CrossRef]

9. Manglik, A.; Kim, T.H.; Masureel, M.; Altenbach, C.; Yang, Z.; Hilger, D.; Lerch, M.T.; Kobilka, T.S.; Thian, F.S.; Hubbell, W.L.; et al. Structural Insights into the Dynamic Process of $\beta 2$-Adrenergic Receptor Signaling. Cell 2015, 161, 1101-1111. [CrossRef]

10. Nakamura, K.; Krupnick, J.G.; Benovic, J.L.; Ascoli, M. Signaling and Phosphorylation-impaired Mutants of the Rat Follitropin Receptor Reveal an Activation- and Phosphorylation-independent but Arrestin-dependent Pathway for Internalization. J. Biol. Chem. 1998, 273, 24346-24354. [CrossRef]

11. Troispoux, C.; Guillou, F.; Elalouf, J.-M.; Firsov, D.; Iacovelli, L.; De Blasi, A.; Combarnous, Y.; Reiter, E. Involvement of $\mathrm{G}$ Protein-Coupled Receptor Kinases and Arrestins in Desensitization to Follicle-Stimulating Hormone Action. Mol. Endocrinol. 1999, 13, 1599-1614. [CrossRef] [PubMed]

12. Lazari, M.F.; Liu, X.; Nakamura, K.; Benovic, J.L.; Ascoli, M. Role of G Protein-Coupled Receptor Kinases on the Agonist-Induced Phosphorylation and Internalization of the Follitropin Receptor. Mol. Endocrinol. 1999, 13, 866-878. [CrossRef] [PubMed]

13. Marion, S.; Robert, F.; Crepieux, P.; Martinat, N.; Troispoux, C.; Guillou, F.; Reiter, E. G protein-coupled receptor kinases and beta arrestins are relocalized and attenuate cyclic $3^{\prime}, 5^{\prime}$-adenosine monophosphate response to follicle-stimulating hormone in rat primary Sertoli cells. Biol. Reprod. 2002, 66, 70-76. [CrossRef] [PubMed]

14. Krishnamurthy, H.; Galet, C.; Ascoli, M. The association of arrestin-3 with the follitropin receptor depends on receptor activation and phosphorylation. Mol. Cell. Endocrinol. 2003, 204, 127-140. [CrossRef]

15. Marion, S.; Kara, E.; Crepieux, P.; Piketty, V.; Martinat, N.; Guillou, F.; Reiter, E. G protein-coupled receptor kinase 2 and -arrestins are recruited to FSH receptor in stimulated rat primary Sertoli cells. J. Endocrinol. 2006, 190, 341-350. [CrossRef]

16. Kara, E.; Crépieux, P.; Gauthier, C.; Martinat, N.; Piketty, V.; Guillou, F.; Reiter, E. A Phosphorylation Cluster of Five Serine and Threonine Residues in the C-Terminus of the Follicle-Stimulating Hormone Receptor Is Important for Desensitization But Not for $\beta$-Arrestin-Mediated ERK Activation. Mol. Endocrinol. 2006, 20, 3014-3026. [CrossRef]

17. Laporte, S.A.; Miller, W.E.; Kim, K.-M.; Caron, M.G. beta-Arrestin/AP-2 interaction in G protein-coupled receptor internalization: Identification of a beta-arrestin binging site in beta 2-adaptin. J. Biol. Chem. 2002, 277, 9247-9254. [CrossRef]

18. Zeleznik, A.J.; Saxena, D.; Little-Ihrig, L. Protein Kinase B Is Obligatory for Follicle-Stimulating Hormone-Induced Granulosa Cell Differentiation. Endocrinology 2003, 144, 3985-3994. [CrossRef]

19. Majumdar, S.S.; Sarda, K.; Bhattacharya, I.; Plant, T.M. Insufficient androgen and FSH signaling may be responsible for the azoospermia of the infantile primate testes despite exposure to an adult-like hormonal milieu. Hum. Reprod. 2012, 27, 2515-2525. [CrossRef] 
20. Bhattacharya, I.; Basu, S.; Pradhan, B.S.; Sarkar, H.; Nagarajan, P.; Majumdar, S.S. Testosterone augments FSH signaling by upregulating the expression and activity of FSH-Receptor in Pubertal Primate Sertoli cells. Mol. Cell. Endocrinol. 2019, 482, 70-80. [CrossRef]

21. Meroni, S.B.; Galardo, M.N.; Rindone, G.; Gorga, A.; Riera, M.F.; Cigorraga, S.B. Molecular Mechanisms and Signaling Pathways Involved in Sertoli Cell Proliferation. Front. Endocrinol. (Lausanne) 2019, 10, 224. [CrossRef] [PubMed]

22. Ulloa-Aguirre, A.; Lira-Albarrán, S. Clinical Applications of Gonadotropins in the Male. Prog. Mol. Biol. Transl. Sci. 2016, 143, 121-174. [PubMed]

23. Arey, B.J.; Stevis, P.E.; Deecher, D.C.; Shen, E.S.; Frail, D.E.; Negro-Vilar, A.; López, F.J. Induction of Promiscuous G Protein Coupling of the Follicle-Stimulating Hormone (FSH) Receptor: A Novel Mechanism for Transducing Pleiotropic Actions of FSH Isoforms. Mol. Endocrinol. 1997, 11, 517-526. [CrossRef] [PubMed]

24. Crépieux, P.; Marion, S.; Martinat, N.; Fafeur, V.; Vern, Y.L.; Kerboeuf, D.; Guillou, F.; Reiter, E. The ERK-dependent signalling is stage-specifically modulated by FSH, during primary Sertoli cell maturation. Oncogene 2001, 20, 4696-4709. [CrossRef]

25. Crépieux, P.; Poupon, A.; Langonné-Gallay, N.; Reiter, E.; Delgado, J.; Schaefer, M.H.; Bourquard, T.; Serrano, L.; Kiel, C. A Comprehensive View of the $\beta$-Arrestinome. Front. Endocrinol. (Lausanne) 2017, 8, 32. [CrossRef]

26. DeWire, S.M.; Ahn, S.; Lefkowitz, R.J.; Shenoy, S.K. ß-Arrestins and Cell Signaling. Annu. Rev. Physiol. 2007, 69, 483-510. [CrossRef]

27. Tréfier, A.; Musnier, A.; Landomiel, F.; Bourquard, T.; Boulo, T.; Ayoub, M.A.; León, K.; Bruneau, G.; Chevalier, M.; Durand, G.; et al. G protein-dependent signaling triggers a $\beta$-arrestin-scaffolded p70S6K/ rpS6 module that controls 5'TOP mRNA translation. FASEB J. 2018, 32, 1154-1169. [CrossRef]

28. Musnier, A.; Heitzler, D.; Boulo, T.; Tesseraud, S.; Durand, G.; Lécureuil, C.; Guillou, H.; Poupon, A.; Reiter, E.; Crépieux, P. Developmental regulation of p70 S6 kinase by a G protein-coupled receptor dynamically modelized in primary cells. Cell. Mol. Life Sci. 2009, 66, 3487-3503. [CrossRef]

29. Das, S.; Maizels, E.T.; DeManno, D.; St Clair, E.; Adam, S.A.; Hunzicker-Dunn, M. A stimulatory role of cyclic adenosine $3^{\prime}, 5^{\prime}$-monophosphate in follicle-stimulating hormone-activated mitogen-activated protein kinase signaling pathway in rat ovarian granulosa cells. Endocrinology 1996, 137, 967-974. [CrossRef]

30. Kayampilly, P.P.; Menon, K.M.J. Inhibition of Extracellular Signal-Regulated Protein Kinase-2 Phosphorylation by Dihydrotestosterone Reduces Follicle-Stimulating Hormone-Mediated Cyclin D2 Messenger Ribonucleic Acid Expression in Rat Granulosa Cells. Endocrinology 2004, 145, 1786-1793. [CrossRef]

31. Casarini, L.; Reiter, E.; Simoni, M. $\beta$-arrestins regulate gonadotropin receptor-mediated cell proliferation and apoptosis by controlling different FSHR or LHCGR intracellular signaling in the hGL5 cell line. Mol. Cell. Endocrinol. 2016, 437, 11-21. [CrossRef] [PubMed]

32. Lécureuil, C.; Tesseraud, S.; Kara, E.; Martinat, N.; Sow, A.; Fontaine, I.; Gauthier, C.; Reiter, E.; Guillou, F.; Crépieux, P. Follicle-stimulating hormone activates p70 ribosomal protein S6 kinase by protein kinase A-mediated dephosphorylation of Thr 421/Ser 424 in primary Sertoli cells. Mol. Endocrinol. 2005, 19, 1812-1820. [CrossRef] [PubMed]

33. León, K.; Boulo, T.; Musnier, A.; Morales, J.; Gauthier, C.; Dupuy, L.; Heyne, S.; Backofen, R.; Poupon, A.; Cormier, P.; et al. Activation of a GPCR leads to eIF4G phosphorylation at the $5^{\prime}$ cap and to IRES-dependent translation. J. Mol. Endocrinol. 2014, 52, 373-382. [CrossRef] [PubMed]

34. Musnier, A.; León, K.; Morales, J.; Reiter, E.; Boulo, T.; Costache, V.; Vourc'h, P.; Heitzler, D.; Oulhen, N.; Poupon, A.; et al. mRNA-selective translation induced by FSH in primary Sertoli cells. Mol. Endocrinol. 2012, 26, 669-680. [CrossRef]

35. Shen, M.; Jiang, Y.; Guan, Z.; Cao, Y.; Li, L.; Liu, H.; Sun, S.C. Protective mechanism of FSH against oxidative damage in mouse ovarian granulosa cells by repressing autophagy. Autophagy 2017, 13, 1364-1385. [CrossRef]

36. Herndon, M.K.; Law, N.C.; Donaubauer, E.M.; Kyriss, B.; Hunzicker-Dunn, M. Forkhead box O member FOXO1 regulates the majority of follicle-stimulating hormone responsive genes in ovarian granulosa cells. Mol. Cell. Endocrinol. 2016, 434, 116-126. [CrossRef] 
37. Park, Y.; Maizels, E.T.; Feiger, Z.J.; Alam, H.; Peters, C.A.; Woodruff, T.K.; Unterman, T.G.; Lee, E.J.; Jameson, J.L.; Hunzicker-Dunn, M. Induction of cyclin D2 in rat granulosa cells requires FSH-dependent relief from FOXO1 repression coupled with positive signals from Smad. J. Biol. Chem. 2005, 280, 9135-9148. [CrossRef]

38. Papaioannou, M.D.; Pitetti, J.-L.; Ro, S.; Park, C.; Aubry, F.; Schaad, O.; Vejnar, C.E.; Kühne, F.; Descombes, P.; Zdobnov, E.M.; et al. Sertoli cell Dicer is essential for spermatogenesis in mice. Dev. Biol. 2009, 326, 250-259. [CrossRef]

39. Gonzalez, G.; Behringer, R.R. Dicer is required for female reproductive tract development and fertility in the mouse. Mol. Reprod. Dev. 2009, 76, 678-688. [CrossRef]

40. Nagaraja, A.K.; Andreu-Vieyra, C.; Franco, H.L.; Ma, L.; Chen, R.; Han, D.Y.; Zhu, H.; Agno, J.E.; Gunaratne, P.H.; DeMayo, F.J.; et al. Deletion of Dicer in somatic cells of the female reproductive tract causes sterility. Mol. Endocrinol. 2008, 22, 2336-2352. [CrossRef]

41. Hong, X.; Luense, L.J.; McGinnis, L.K.; Nothnick, W.B.; Christenson, L.K. Dicer1 is essential for female fertility and normal development of the female reproductive system. Endocrinology 2008, 149, 6207-6212. [CrossRef] [PubMed]

42. Tu, J.; Yang, Y.; Cheung, H.-H.; Chen, Z.-J.; Chan, W.-Y. Conserved miR-10 family represses proliferation and induces apoptosis in ovarian granulosa cells. Sci. Rep. 2017, 7, 41304.

43. Nicholls, P.K.; Harrison, C.A.; Walton, K.L.; McLachlan, R.I.; O’Donnell, L.; Stanton, P.G. Hormonal regulation of sertoli cell micro-RNAs at spermiation. Endocrinology 2011, 152, 1670-1683. [CrossRef] [PubMed]

44. Dupont, J.; Musnier, A.; Decourtye, J.; Boulo, T.; Lécureuil, C.; Guillou, H.; Valet, S.; Fouchécourt, S.; Pitetti, J.L.; Nef, S.; et al. FSH-stimulated PTEN activity accounts for the lack of FSH mitogenic effect in prepubertal rat Sertoli cells. Mol. Cell. Endocrinol. 2010, 315, 271-276. [CrossRef] [PubMed]

45. Casarini, L.; Simoni, M.; Brigante, G. Is polycystic ovary syndrome a sexual conflict? A review. Reprod. Biomed. Online 2016, 32, 350-361. [CrossRef]

46. Casarini, L.; Santi, D.; Marino, M. Impact of gene polymorphisms of gonadotropins and their receptors on human reproductive success. Reproduction 2015, 150, R175-R184. [CrossRef]

47. Casarini, L.; Brigante, G.; Simoni, M.; Santi, D. Clinical Applications of Gonadotropins in the Female: Assisted Reproduction and Beyond. Prog. Mol. Biol. Transl. Sci. 2016, 143, 85-119.

48. Young, J.; Xu, C.; Papadakis, G.E.; Acierno, J.S.; Maione, L.; Hietamäki, J.; Raivio, T.; Pitteloud, N. Clinical Management of Congenital Hypogonadotropic Hypogonadism. Endocr. Rev. 2019, 40, 669-710. [CrossRef]

49. Lunenfeld, B.; Bilger, W.; Longobardi, S.; Alam, V.; D’Hooghe, T.; Sunkara, S.K. The Development of Gonadotropins for Clinical Use in the Treatment of Infertility. Front. Endocrinol. (Lausanne) 2019, 10, 429. [CrossRef]

50. Bassett, R.; Driebergen, R. Continued improvements in the quality and consistency of follitropin alfa, recombinant human FSH. Reprod. Biomed. Online 2005, 10, 169-177. [CrossRef]

51. Santi, D.; Simoni, M. Biosimilar recombinant follicle stimulating hormones in infertility treatment. Expert Opin. Biol. Ther. 2014, 14, 1399-1409. [CrossRef] [PubMed]

52. Wide, L.; Eriksson, K. Dynamic changes in glycosylation and glycan composition of serum FSH and LH during natural ovarian stimulation. Ups. J. Med. Sci. 2013, 118, 153-164. [CrossRef] [PubMed]

53. Mastrangeli, R.; Satwekar, A.; Cutillo, F.; Ciampolillo, C.; Palinsky, W.; Longobardi, S. In-vivo biological activity and glycosylation analysis of a biosimilar recombinant human follicle-stimulating hormone product (Bemfola) compared with its reference medicinal product (GONAL-f). PLoS ONE 2017, 12, e0184139. [CrossRef] [PubMed]

54. Butnev, V.Y.; Butnev, V.Y.; May, J.V.; Shuai, B.; Tran, P.; White, W.K.; Brown, A.; Smalter Hall, A.; Harvey, D.J.; Bousfield, G.R. Production, purification, and characterization of recombinant $\mathrm{hFSH}$ glycoforms for functional studies. Mol. Cell. Endocrinol. 2015, 405, 42-51. [CrossRef] [PubMed]

55. Helenius, A.; Aebi, M. Intracellular functions of N-linked glycans. Science 2001, 291, 2364-2369. [CrossRef]

56. Ulloa-Aguirre, A.; Timossi, C.; Damián-Matsumura, P.; Dias, J.A. Role of Glycosylation in Function of Follicle-Stimulating Hormone. Endocrine 1999, 11, 205-216. [CrossRef] 
57. Ulloa-Aguirre, A.; Timossi, C.; Barrios-de-Tomasi, J.; Maldonado, A.; Nayudu, P. Impact of Carbohydrate Heterogeneity in Function of Follicle-Stimulating Hormone: Studies Derived from in Vitro and in Vivo Models1. Biol. Reprod. 2003, 69, 379-389. [CrossRef]

58. Bousfield, G.R.; May, J.V.; Davis, J.S.; Dias, J.A.; Kumar, T.R. In Vivo and In Vitro Impact of Carbohydrate Variation on Human Follicle-Stimulating Hormone Function. Front. Endocrinol. (Lausanne) 2018, 9, 216. [CrossRef]

59. Campo, S.; Andreone, L.; Ambao, V.; Urrutia, M.; Calandra, R.S.; Rulli, S.B. Hormonal Regulation of Follicle-Stimulating Hormone Glycosylation in Males. Front. Endocrinol. (Lausanne) 2019, 10, 17. [CrossRef]

60. Meher, B.R.; Dixit, A.; Bousfield, G.R.; Lushington, G.H. Glycosylation Effects on FSH-FSHR Interaction Dynamics: A Case Study of Different FSH Glycoforms by Molecular Dynamics Simulations. PLoS ONE 2015, 10, e0137897. [CrossRef]

61. Núñez Miguel, R.; Sanders, J.; Furmaniak, J.; Rees Smith, B. Glycosylation pattern analysis of glycoprotein hormones and their receptors. J. Mol. Endocrinol. 2017, 58, 25-41. [CrossRef] [PubMed]

62. Jiang, C.; Hou, X.; Wang, C.; May, J.V.; Butnev, V.Y.; Bousfield, G.R.; Davis, J.S. Hypoglycosylated hFSH Has Greater Bioactivity Than Fully Glycosylated Recombinant hFSH in Human Granulosa Cells. J. Clin. Endocrinol. Metab. 2015, 100, E852-E860. [CrossRef] [PubMed]

63. Arey, B.J.; López, F.J. Are circulating gonadotropin isoforms naturally occurring biased agonists? Basic and therapeutic implications. Rev. Endocr. Metab. Disord. 2011, 12, 275-288. [CrossRef] [PubMed]

64. Bousfield, G.R.; Butnev, V.Y.; Butnev, V.Y.; Hiromasa, Y.; Harvey, D.J.; May, J.V. Hypo-glycosylated human follicle-stimulating hormone $(\mathrm{hFSH}(21 / 18)$ ) is much more active in vitro than fully-glycosylated $\mathrm{hFSH}$ (hFSH(24)). Mol. Cell. Endocrinol. 2014, 382, 989-997. [CrossRef]

65. Wang, H.; May, J.; Butnev, V.; Shuai, B.; May, J.V.; Bousfield, G.R.; Kumar, T.R. Evaluation of in vivo bioactivities of recombinant hypo- (FSH 21/18) and fully- (FSH 24 ) glycosylated human FSH glycoforms in Fshb null mice. Mol. Cell. Endocrinol. 2016, 437, 224-236. [CrossRef]

66. Timossi, C.; Damian-Matsumura, P.; Dominguez-Gonzalez, A.; Ulloa-Aguirre, A. A less acidic human follicle-stimulating hormone preparation induces tissue-type plasminogen activator enzyme activity earlier than a predominantly acidic analogue in phenobarbital-blocked pro-oestrous rats. Mol. Hum. Reprod. 1998, 4, 1032-1038. [CrossRef]

67. Howles, C.M. Role of LH and FSH in ovarian function. Mol. Cell. Endocrinol. 2000, 161, 25-30. [CrossRef]

68. Fares, F. The role of O-linked and N-linked oligosaccharides on the structure-function of glycoprotein hormones: Development of agonists and antagonists. Biochim. Biophys. Acta Gen. Subj. 2006, 1760, 560-567. [CrossRef]

69. Anobile, C.J.; Talbot, J.A.; McCann, S.J.; Padmanabhan, V.; Robertson, W.R. Glycoform composition of serum gonadotrophins through the normal menstrual cycle and in the post-menopausal state. Mol. Hum. Reprod. 1998, 4, 631-639. [CrossRef]

70. Selman, H.; Pacchiarotti, A.; El-Danasouri, I. Ovarian stimulation protocols based on follicle-stimulating hormone glycosylation pattern: Impact on oocyte quality and clinical outcome. Fertil. Steril. 2010, 94, 1782-1786. [CrossRef]

71. Perlman, S.; van den Hazel, B.; Christiansen, J.; Gram-Nielsen, S.; Jeppesen, C.B.; Andersen, K.V.; Halkier, T.; Okkels, S.; Schambye, H.T. Glycosylation of an N-Terminal Extension Prolongs the Half-Life and Increases the in Vivo Activity of Follicle Stimulating Hormone. J. Clin. Endocrinol. Metab. 2003, 88, 3227-3235. [CrossRef] [PubMed]

72. Liu, P.Y.; Turner, L.; Rushford, D.; McDonald, J.; Baker, H.W.; Conway, A.J. Efficacy and safety of recombinant human follicle stimulating hormone (Gonal-F) with urinary human chorionic gonadotrophin for induction of spermatogenesis and fertility in gonadotrophin-deficient men. Hum. Reprod. 1999, 14, 1540-1545. [CrossRef] [PubMed]

73. Goa, K.L.; Wagstaff, A.J. Follitropin Alpha in Infertility. BioDrugs 1998, 9, 235-260. [CrossRef] [PubMed]

74. Creus, S.; Chaia, Z.; Pellizzari, E.H.; Cigorraga, S.B.; Ulloa-Aguirre, A.; Campo, S. Human FSH isoforms: Carbohydrate complexity as determinant of in-vitro bioactivity. Mol. Cell. Endocrinol. 2001, 174, 41-49. [CrossRef]

75. Olijve, W.; de Boer, W.; Mulders, J.W.; van Wezenbeek, P.M. Molecular biology and biochemistry of human recombinant follicle stimulating hormone (Puregon). Mol. Hum. Reprod. 1996, 2, 371-382. [CrossRef] 
76. Olsson, H.; Sandström, R.; Grundemar, L. Different pharmacokinetic and pharmacodynamic properties of recombinant follicle-stimulating hormone $(\mathrm{rFSH})$ derived from a human cell line compared with $\mathrm{rFSH}$ from a non-human cell line. J. Clin. Pharmacol. 2014, 54, 1299-1307. [CrossRef]

77. Abd-Elaziz, K.; Duijkers, I.; Stöckl, L.; Dietrich, B.; Klipping, C.; Eckert, K.; Goletz, S. A new fully human recombinant FSH (follitropin epsilon): Two phase I randomized placebo and comparator-controlled pharmacokinetic and pharmacodynamic trials. Hum. Reprod. 2017, 32, 1639-1647. [CrossRef]

78. Griesinger, G.; Dietrich, B.; Stöckl, L.; Eckert, K.; Goletz, S.; Tandler-Schneider, A. Fully human glyco-optimized recombinant FSH (follitropin epsilon)—Arandomized, comparator-controlled phase II clinical trial. Reprod. Biomed. Online 2020, 40, 331-341. [CrossRef]

79. Riccetti, L.; Sperduti, S.; Lazzaretti, C.; Klett, D.; De Pascali, F.; Paradiso, E.; Limoncella, S.; Potì, F.; Tagliavini, S.; Trenti, T.; et al. Glycosylation Pattern and in vitro Bioactivity of Reference Follitropin alfa and Biosimilars. Front. Endocrinol. (Lausanne) 2019, 10, 503. [CrossRef]

80. Koechling, W.; Plaksin, D.; Croston, G.E.; Jeppesen, J.V.; Macklon, K.T.; Andersen, C.Y. Comparative pharmacology of a new recombinant FSH expressed by a human cell line. Endocr. Connect. 2017, 6, 297-305. [CrossRef]

81. Pouwer, A.W.; Farquhar, C.; Kremer, J.A.M. Long-acting FSH versus daily FSH for women undergoing assisted reproduction. Cochrane Database Syst. Rev. 2015, CD009577. [CrossRef] [PubMed]

82. Cole, L.A. hCG, the wonder of today's science. Reprod. Biol. Endocrinol. 2012, 10, 24. [CrossRef] [PubMed]

83. Casarini, L.; Santi, D.; Brigante, G.; Simoni, M. Two Hormones for One Receptor: Evolution, Biochemistry, Actions, and Pathophysiology of LH and hCG. Endocr. Rev. 2018, 39, 549-592. [CrossRef] [PubMed]

84. Verbost, P.; Sloot, W.N.; Rose, U.M.; de Leeuw, R.; Hanssen, R.G.J.M.; Verheijden, G.F.M. Pharmacologic profiling of corifollitropin alfa, the first developed sustained follicle stimulant. Eur. J. Pharmacol. 2011, 651, 227-233. [CrossRef]

85. Fauser, B.C.J.M.; Alper, M.M.; Ledger, W.; Schoolcraft, W.B.; Zandvliet, A.; Mannaerts, B.M.J.L.; Engage Investigators. Pharmacokinetics and follicular dynamics of corifollitropin alfa versus recombinant FSH during ovarian stimulation for IVF. Reprod. Biomed. Online 2010, 21, 593-601. [CrossRef]

86. Fares, F.A.; Suganuma, N.; Nishimori, K.; LaPolt, P.S.; Hsueh, A.J.; Boime, I. Design of a long-acting follitropin agonist by fusing the $\mathrm{C}$-terminal sequence of the chorionic gonadotropin beta subunit to the follitropin beta subunit. Proc. Natl. Acad. Sci. USA 1992, 89, 4304-4308. [CrossRef]

87. De Lartigue, J. Corifollitropin alfa: A new option to treat female infertility. Drugs Today 2011, 47, 583-590.

88. Sacchi, S.; Tenedini, E.; Tondelli, D.; Parenti, S.; Tagliasacchi, D.; Xella, S.; Marsella, T.; Tagliafico, E.; La Marca, A. Gene expression profiles of human granulosa cells treated with bioequivalent doses of corifollitropin alfa (CFA) or recombinant human follicle-stimulating hormone (recFSH). Gynecol. Endocrinol. 2019, 35, 623-627. [CrossRef]

89. Fensore, S.; Di Marzio, M.; Tiboni, G.M. Corifollitropin alfa compared to daily FSH in controlled ovarian stimulation for in vitro fertilization: A meta-analysis. J. Ovarian Res. 2015, 8, 33. [CrossRef]

90. Jonas, K.C.; Chen, S.; Virta, M.; Mora, J.; Franks, S.; Huhtaniemi, I.; Hanyaloglu, A.C. Temporal reprogramming of calcium signalling via crosstalk of gonadotrophin receptors that associate as functionally asymmetric heteromers. Sci. Rep. 2018, 8, 2239. [CrossRef]

91. Rivero-Müller, A.; Chou, Y.-Y.; Ji, I.; Lajic, S.; Hanyaloglu, A.C.; Jonas, K.; Rahman, N.; Ji, T.H.; Huhtaniemi, I. Rescue of defective $\mathrm{G}$ protein-coupled receptor function in vivo by intermolecular cooperation. Proc. Natl. Acad. Sci. USA 2010, 107, 2319-2324. [CrossRef] [PubMed]

92. Feng, X.; Zhang, M.; Guan, R.; Segaloff, D.L. Heterodimerization Between the Lutropin and Follitropin Receptors is Associated With an Attenuation of Hormone-Dependent Signaling. Endocrinology 2013, 154, 3925-3930. [CrossRef] [PubMed]

93. Mao, J.-F.; Liu, Z.X.; Nie, M.; Wang, X.; Xu, H.L.; Huang, B.K.; Zheng, J.J.; Min, L.; Kaiser, U.; Wu, X.Y. Pulsatile gonadotropin-releasing hormone therapy is associated with earlier spermatogenesis compared to combined gonadotropin therapy in patients with congenital hypogonadotropic hypogonadism. Asian J. Androl. 2017, 19, 680. [PubMed]

94. Salenave, S.; Trabado, S.; Maione, L.; Brailly-Tabard, S.; Young, J. Male acquired hypogonadotropic hypogonadism: Diagnosis and treatment. Ann. Endocrinol. 2012, 73, 141-146. [CrossRef] [PubMed]

95. Bianco, S.D.C.; Kaiser, U.B. The genetic and molecular basis of idiopathic hypogonadotropic hypogonadism. Nat. Rev. Endocrinol. 2009, 5, 569-576. [CrossRef] [PubMed] 
96. Krausz, C. Male infertility: Pathogenesis and clinical diagnosis. Best Pract. Res. Clin. Endocrinol. Metab. 2011, 25, 271-285. [CrossRef]

97. Zheng, J.; Mao, J.; Cui, M.; Liu, Z.; Wang, X.; Xiong, S.; Nie, M.; Wu, X. Novel FSH $\beta$ mutation in a male patient with isolated FSH deficiency and infertility. Eur. J. Med. Genet. 2017, 60, 335-339. [CrossRef]

98. Sykiotis, G.P.; Hoang, X.-H.; Avbelj, M.; Hayes, F.J.; Thambundit, A.; Dwyer, A.; Au, M.; Plummer, L.; Crowley, W.F.; Pitteloud, N. Congenital idiopathic hypogonadotropic hypogonadism: Evidence of defects in the hypothalamus, pituitary, and testes. J. Clin. Endocrinol. Metab. 2010, 95, 3019-3027. [CrossRef]

99. Pitteloud, N.; Hayes, F.J.; Dwyer, A.; Boepple, P.A.; Lee, H.; Crowley, W.F. Predictors of Outcome of Long-Term GnRH Therapy in Men with Idiopathic Hypogonadotropic Hypogonadism. J. Clin. Endocrinol. Metab. 2002, 87, 4128-4136. [CrossRef]

100. Delemarre-Van de Waal, H.A.; Odink, R.J. Pulsatile GnRH treatment in boys and girls with idiopathic hypogonadotrophic hypogonadism. Hum. Reprod. 1993, 8, 180-183. [CrossRef]

101. Rastrelli, G.; Corona, G.; Mannucci, E.; Maggi, M. Factors affecting spermatogenesis upon gonadotropin-replacement therapy: A meta-analytic study. Andrology 2014, 2, 794-808. [CrossRef] [PubMed]

102. World Health Organization. WHO Laboratory Manual for the Examination and Processing of Human Semen; World Health Organization: Geneva, Switzerland, 2010.

103. Herbison, A.E. The Gonadotropin-Releasing Hormone Pulse Generator. Endocrinology 2018, 159, 3723-3736. [CrossRef] [PubMed]

104. Riccetti, L.; Yvinec, R.; Klett, D.; Gallay, N.; Combarnous, Y.; Reiter, E.; Simoni, M.; Casarini, L.; Ayoub, M.A. Human Luteinizing Hormone and Chorionic Gonadotropin Display Biased Agonism at the LH and LH/CG Receptors. Sci. Rep. 2017, 7, 940. [CrossRef] [PubMed]

105. Riccetti, L.; De Pascali, F.; Gilioli, L.; Potì, F.; Giva, L.B.; Marino, M.; Tagliavini, S.; Trenti, T.; Fanelli, F.; Mezzullo, M.; et al. Human LH and hCG stimulate differently the early signalling pathways but result in equal testosterone synthesis in mouse Leydig cells in vitro. Reprod. Biol. Endocrinol. 2017, 15, 2. [CrossRef]

106. Simoni, M.; Santi, D.; Negri, L.; Hoffmann, I.; Muratori, M.; Baldi, E.; Cambi, M.; Marcou, M.; Greither, T.; Baraldi, E.; et al. Treatment with human, recombinant FSH improves sperm DNA fragmentation in idiopathic infertile men depending on the FSH receptor polymorphism p.N680S: A pharmacogenetic study. Hum. Reprod. 2016, 31, 1960-1969. [CrossRef]

107. Colacurci, N.; De Leo, V.; Ruvolo, G.; Piomboni, P.; Caprio, F.; Pivonello, R.; Papaleo, E.; La Verde, E.; Depalo, R.; Lispi, M.; et al. Recombinant FSH Improves Sperm DNA Damage in Male Infertility: A Phase II Clinical Trial. Front. Endocrinol. (Lausanne) 2018, 9, 383. [CrossRef]

108. Patel, D.P.; Chandrapal, J.C.; Hotaling, J.M. Hormone-Based Treatments in Subfertile Males. Curr. Urol. Rep. 2016, 17, 56. [CrossRef]

109. Cannarella, R.; Condorelli, R.A.; Mongioì, L.M.; Barbagallo, F.; Calogero, A.E.; La Vignera, S. Effects of the selective estrogen receptor modulators for the treatment of male infertility: A systematic review and meta-analysis. Expert Opin. Pharmacother. 2019, 20, 1517-1525. [CrossRef]

110. Lunan, C.B.; Klopper, A. Antioestrogens: A review. Clin. Endocrinol. (Oxf.) 1975, 4, 551-572. [CrossRef]

111. Chua, M.E.; Escusa, K.G.; Luna, S.; Tapia, L.C.; Dofitas, B.; Morales, M. Revisiting oestrogen antagonists (clomiphene or tamoxifen) as medical empiric therapy for idiopathic male infertility: A meta-analysis. Andrology 2013, 1, 749-757. [CrossRef]

112. Barbonetti, A.; Calogero, A.E.; Balercia, G.; Garolla, A.; Krausz, C.; La Vignera, S.; Lombardo, F.; Jannini, E.A.; Maggi, M.; Lenzi, A.; et al. The use of follicle stimulating hormone (FSH) for the treatment of the infertile man: Position statement from the Italian Society of Andrology and Sexual Medicine (SIAMS). J. Endocrinol. Investig. 2018, 41, 1107-1122. [CrossRef] [PubMed]

113. Colpi, G.M.; Francavilla, S.; Haidl, G.; Link, K.; Behre, H.M.; Goulis, D.G.; Krausz, C.; Giwercman, A. European Academy of Andrology guideline Management of oligo-astheno-teratozoospermia. Andrology 2018, 6, 513-524. [CrossRef] [PubMed]

114. Chehab, M.; Madala, A.; Trussell, J.C. On-label and off-label drugs used in the treatment of male infertility. Fertil. Steril. 2015, 103, 595-604. [CrossRef] [PubMed]

115. Simoni, M.; Santi, D. FSH treatment of male idiopathic infertility: Time for a paradigm change. Andrology 2020, 12746. [CrossRef] 
116. Santi, D.; Granata, A.R.M.; Simoni, M. FSH treatment of male idiopathic infertility improves pregnancy rate: A meta-analysis. Endocr. Connect. 2015, 4, R46-R58. [CrossRef]

117. Attia, A.M.; Abou-Setta, A.M.; Al-Inany, H.G. Gonadotrophins for idiopathic male factor subfertility. Cochrane Database Syst. Rev. 2013, CD005071. [CrossRef]

118. Foresta, C.; Selice, R.; Ferlin, A.; Garolla, A. Recombinant FSH in the treatment of oligozoospermia. Expert Opin. Biol. Ther. 2009, 9, 659-666. [CrossRef]

119. Ding, Y.; Zhang, X.; Li, J.P.; Chen, S.; Zhang, R.; Tan, W.; Shi, X.J. Treatment of idiopathic oligozoospermia with recombinant human follicle-stimulating hormone: A prospective, randomized, double-blind, placebo-controlled clinical study in Chinese population. Clin. Endocrinol. (Oxf). 2015, 83, 866-871. [CrossRef]

120. Foresta, C.; Bettella, A.; Merico, M.; Garolla, A.; Ferlin, A.; Rossato, M. Use of recombinant human follicle-stimulating hormone in the treatment of male factor infertility. Fertil. Steril. 2002, 77, 238-244. [CrossRef]

121. Grigorova, M.; Punab, M.; Poolamets, O.; Sõber, S.; Vihljajev, V.; Žilaitiene, B.; Erenpreiss, J.; Matulevičius, V.; Tsarev, I.; Laan, M. Study in 1790 Baltic men: FSHR Asn680Ser polymorphism affects total testes volume. Andrology 2013, 1, 293-300. [CrossRef]

122. Casarini, L.; Moriondo, V.; Marino, M.; Adversi, F.; Capodanno, F.; Grisolia, C.; La Marca, A.; La Sala, G.B.; Simoni, M. FSHR polymorphism p.N680S mediates different responses to FSH in vitro. Mol. Cell. Endocrinol. 2014, 393, 83-91. [CrossRef] [PubMed]

123. Selice, R.; Garolla, A.; Pengo, M.; Caretta, N.; Ferlin, A.; Foresta, C. The response to FSH treatment in oligozoospermic men depends on FSH receptor gene polymorphisms. Int. J. Androl. 2011, 34, 306-312. [CrossRef] [PubMed]

124. Wunsch, A.; Ahda, Y.; Banaz-Yaşar, F.; Sonntag, B.; Nieschlag, E.; Simoni, M.; Gromoll, J. Single-nucleotide polymorphisms in the promoter region influence the expression of the human follicle-stimulating hormone receptor. Fertil. Steril. 2005, 84, 446-453. [CrossRef] [PubMed]

125. Tamburino, L.; La Vignera, S.; Tomaselli, V.; Condorelli, R.A.; Cannarella, R.; Mongioì, L.M.; Calogero, A.E. The $-29 \mathrm{G} / \mathrm{A}$ FSH receptor gene polymorphism is associated with higher FSH and LH levels in normozoospermic men. J. Assist. Reprod. Genet. 2017, 34, 1289-1294. [CrossRef]

126. Grigorova, M.; Punab, M.; Punab, A.M.; Poolamets, O.; Vihljajev, V.; Žilaitiene, B.; Erenpreiss, J.; Matulevičius, V.; Laan, M. Reproductive Physiology in Young Men Is Cumulatively Affected by FSH-Action Modulating Genetic Variants: FSHR -29G/A and c.2039 A/G, FSHB -211G/T. PLoS ONE 2014, 9, e94244. [CrossRef]

127. Benson, C.A.; Kurz, T.L.; Thackray, V.G. A Human FSHB Promoter SNP Associated With Low FSH Levels in Men Impairs LHX3 Binding and Basal FSHB Transcription. Endocrinology 2013, 154, 3016-3021. [CrossRef]

128. Busch, A.S.; Tüttelmann, F.; Cremers, J.-F.; Schubert, M.; Nordhoff, V.; Schüring, A.N.; Zitzmann, M.; Gromoll, J.; Kliesch, S. FSHB -211 G>T Polymorphism as Predictor for TESE Success in Patients with Unexplained Azoospermia. J. Clin. Endocrinol. Metab. 2019, 104, 2315-2324. [CrossRef]

129. Ferlin, A.; Vinanzi, C.; Selice, R.; Garolla, A.; Frigo, A.C.; Foresta, C. Toward a pharmacogenetic approach to male infertility: Polymorphism of follicle-stimulating hormone beta-subunit promoter. Fertil. Steril. 2011, 96, 1344-1349.e2. [CrossRef]

130. Grigorova, M.; Punab, M.; Ausmees, K.; Laan, M. FSHB promoter polymorphism within evolutionary conserved element is associated with serum FSH level in men. Hum. Reprod. 2008, 23, 2160-2166. [CrossRef]

131. Simoni, M.; Casarini, L. Mechanisms in endocrinology: Genetics of FSH action: A 2014-and-beyond view. Eur. J. Endocrinol. 2014, 170, R91-R107. [CrossRef]

132. Tüttelmann, F.; Laan, M.; Grigorova, M.; Punab, M.; Sõber, S.; Gromoll, J. Combined Effects of the Variants FSHB -211G>T and FSHR 2039A > G on Male Reproductive Parameters. J. Clin. Endocrinol. Metab. 2012, 97, 3639-3647. [CrossRef] [PubMed]

133. Wacker, D.; Wang, C.; Katritch, V.; Han, G.W.; Huang, X.P.; Vardy, E.; McCorvy, J.D.; Jiang, Y.; Chu, M.; Siu, F.Y.; et al. Structural features for functional selectivity at serotonin receptors. Science 2013, 340, 615-619. [CrossRef] [PubMed]

134. Nygaard, R.; Zou, Y.; Dror, R.O.; Mildorf, T.J.; Arlow, D.H.; Manglik, A.; Pan, A.C.; Liu, C.W.; Fung, J.J.; Bokoch, M.P.; et al. The dynamic process of $\beta(2)$-adrenergic receptor activation. Cell 2013, 152, 532-542. [CrossRef] [PubMed] 
135. Kobilka, B.K. Structural insights into adrenergic receptor function and pharmacology. Trends Pharmacol. Sci. 2011, 32, 213-218. [CrossRef] [PubMed]

136. Watson, C.; Chen, G.; Irving, P.; Way, J.; Chen, W.J.; Kenakin, T. The use of stimulus-biased assay systems to detect agonist-specific receptor active states: Implications for the trafficking of receptor stimulus by agonists. Mol. Pharmacol. 2000, 58, 1230-1238. [CrossRef]

137. Galandrin, S.; Oligny-Longpré, G.; Bouvier, M. The evasive nature of drug efficacy: Implications for drug discovery. Trends Pharmacol. Sci. 2007, 28, 423-430. [CrossRef]

138. Violin, J.D.; Lefkowitz, R.J. $\beta$-Arrestin-biased ligands at seven-transmembrane receptors. Trends Pharmacol. Sci. 2007, 28, 416-422. [CrossRef]

139. Reiter, E.; Ahn, S.; Shukla, A.K.; Lefkowitz, R.J. Molecular mechanism of $\beta$-arrestin-biased agonism at seven-transmembrane receptors. Annu. Rev. Pharmacol. Toxicol. 2012, 52, 179-197. [CrossRef]

140. Kenakin, T. Ligand-selective receptor conformations revisited: The promise and the problem. Trends Pharmacol. Sci. 2003, 24, 346-354. [CrossRef]

141. Wootten, D.; Christopoulos, A.; Marti-Solano, M.; Babu, M.M.; Sexton, P.M. Mechanisms of signalling and biased agonism in G protein-coupled receptors. Nat. Rev. Mol. Cell Biol. 2018, 19, 638-653. [CrossRef]

142. Changeux, J.-P.; Christopoulos, A. Allosteric Modulation as a Unifying Mechanism for Receptor Function and Regulation. Cell 2016, 166, 1084-1102. [CrossRef] [PubMed]

143. Whalen, E.J.; Rajagopal, S.; Lefkowitz, R.J. Therapeutic potential of $\beta$-arrestin- and G protein-biased agonists. Trends Mol. Med. 2011, 17, 126-139. [CrossRef] [PubMed]

144. Bond, R.A.; Lucero Garcia-Rojas, E.Y.; Hegde, A.; Walker, J.K.L. Therapeutic Potential of Targeting B-Arrestin. Front. Pharmacol. 2019, 10, 124. [CrossRef] [PubMed]

145. Yanofsky, S.D.; Shen, E.S.; Holden, F.; Whitehorn, E.; Aguilar, B.; Tate, E.; Holmes, C.P.; Scheuerman, R.; MacLean, D.; Wu, M.M.; et al. Allosteric activation of the follicle-stimulating hormone (FSH) receptor by selective, nonpeptide agonists. J. Biol. Chem. 2006, 281, 13226-13233. [CrossRef]

146. Arey, B.J.; Yanofsky, S.D.; Claudia Pérez, M.; Holmes, C.P.; Wrobel, J.; Gopalsamy, A.; Stevis, P.E.; López, F.J.; Winneker, R.C. Differing pharmacological activities of thiazolidinone analogs at the FSH receptor. Biochem. Biophys. Res. Commun. 2008, 368, 723-728. [CrossRef]

147. Sriraman, V.; Denis, D.; de Matos, D.; Yu, H.; Palmer, S.; Nataraja, S. Investigation of a thiazolidinone derivative as an allosteric modulator of follicle stimulating hormone receptor: Evidence for its ability to support follicular development and ovulation. Biochem. Pharmacol. 2014, 89, 266-275. [CrossRef]

148. Yu, H.N.; Richardson, T.E.; Nataraja, S.; Fischer, D.J.; Sriraman, V.; Jiang, X.; Bharathi, P.; Foglesong, R.J.; Haxell, T.F.N.; Heasley, B.H.; et al. Discovery of substituted benzamides as follicle stimulating hormone receptor allosteric modulators. Bioorg. Med. Chem. Lett. 2014, 24, 2168-2172. [CrossRef]

149. Van Koppen, C.J.; Verbost, P.M.; van de Lagemaat, R.; Karstens, W.J.F.; Loozen, H.J.J.; van Achterberg, T.A.E.; van Amstel, M.G.A.; Brands, J.H.G.M.; van Doornmalen, E.J.P.; Wat, J.; et al. Signaling of an allosteric, nanomolar potent, low molecular weight agonist for the follicle-stimulating hormone receptor. Biochem. Pharmacol. 2013, 85, 1162-1170. [CrossRef]

150. Van Straten, N.C.R.; van Berkel, T.H.J.; Demont, D.R.; Karstens, W.J.F.; Merkx, R.; Oosterom, J.; Schulz, J.; van Someren, R.G.; Timmers, C.M.; van Zandvoort, P.M. Identification of substituted 6-amino-4-phenyltetrahydroquinoline derivatives: Potent antagonists for the follicle-stimulating hormone receptor. J. Med. Chem. 2005, 48, 1697-1700. [CrossRef]

151. Dias, J.A.; Bonnet, B.; Weaver, B.A.; Watts, J.; Kluetzman, K.; Thomas, R.M.; Poli, S.; Mutel, V.; Campo, B. A negative allosteric modulator demonstrates biased antagonism of the follicle stimulating hormone receptor. Mol. Cell. Endocrinol. 2011, 333, 143-150. [CrossRef]

152. Dias, J.A.; Campo, B.; Weaver, B.A.; Watts, J.; Kluetzman, K.; Thomas, R.M.; Bonnet, B.; Mutel, V.; Poli, S.M. Inhibition of follicle-stimulating hormone-induced preovulatory follicles in rats treated with a nonsteroidal negative allosteric modulator of follicle-stimulating hormone receptor. Biol. Reprod. 2014, 90, 19. [CrossRef] [PubMed]

153. Ayoub, M.A.; Yvinec, R.; Jégot, G.; Dias, J.A.; Poli, S.M.; Poupon, A.; Crépieux, P.; Reiter, E. Profiling of FSHR negative allosteric modulators on LH/CGR reveals biased antagonism with implications in steroidogenesis. Mol. Cell. Endocrinol. 2016, 436, 10-22. [CrossRef] [PubMed]

154. Anderson, R.C.; Newton, C.L.; Anderson, R.A.; Millar, R.P. Gonadotropins and Their Analogs: Current and Potential Clinical Applications. Endocr. Rev. 2018, 39, 911-937. [CrossRef] 
155. Sugahara, T.; Pixley, M.R.; Minami, S.; Perlas, E.; Ben-Menahem, D.; Hsueh, A.J.; Boime, I. Biosynthesis of a biologically active single peptide chain containing the human common alpha and chorionic gonadotropin beta subunits in tandem. Proc. Natl. Acad. Sci. USA 1995, 92, 2041-2045. [CrossRef] [PubMed]

156. Klein, J.; Lobel, L.; Pollak, S.; Ferin, M.; Xiao, E.; Sauer, M.; Lustbader, J. Pharmacokinetics and pharmacodynamics of single-chain recombinant human follicle-stimulating hormone containing the human chorionic gonadotropin carboxyterminal peptide in the rhesus monkey. Fertil. Steril. 2002, 77, 1248-1255. [CrossRef]

157. Sugahara, T.; Grootenhuis, P.D.; Sato, A.; Kudo, M.; Ben-Menahem, D.; Pixley, M.R.; Hsueh, A.J.; Boime, I. Expression of biologically active fusion genes encoding the common alpha subunit and either the CG beta or FSH beta subunits: Role of a linker sequence. Mol. Cell. Endocrinol. 1996, 125, 71-77. [CrossRef]

158. Lemke, E.P.; Adams, B.M.; Jablonka-Shariff, A.; Boime, I.; Adams, T.E. Single-chain human gonadotropin analogs induce follicle development in sheep. J. Endocrinol. 2008, 196, 593-600. [CrossRef]

159. Rutigliano, H.M.; Adams, B.M.; Jablonka-Shariff, A.; Boime, I.; Adams, T.E. Effect of single-chain ovine gonadotropins with dual activity on ovarian function in sheep. Reproduction 2014, 148, 129-136. [CrossRef]

160. Kanda, M.; Jablonka-Shariff, A.; Sato, A.; Pixley, M.R.; Bos, E.; Hiro'oka, T.; Ben-Menahem, D.; Boime, I. Genetic fusion of an alpha-subunit gene to the follicle-stimulating hormone and chorionic gonadotropin-beta subunit genes: Production of a bifunctional protein. Mol. Endocrinol. 1999, 13, 1873-1881.

161. Hutchings, C.J.; Koglin, M.; Olson, W.C.; Marshall, F.H. Opportunities for therapeutic antibodies directed at G-protein-coupled receptors. Nat. Rev. Drug Discov. 2017, 16, 787-810. [CrossRef]

162. Mujić-Delić, A.; de Wit, R.H.; Verkaar, F.; Smit, M.J. GPCR-targeting nanobodies: Attractive research tools, diagnostics, and therapeutics. Trends Pharmacol. Sci. 2014, 35, 247-255. [CrossRef] [PubMed]

163. Staus, D.P.; Strachan, R.T.; Manglik, A.; Pani, B.; Kahsai, A.W.; Kim, T.H.; Wingler, L.M.; Ahn, S.; Chatterjee, A.; Masoudi, A.; et al. Allosteric nanobodies reveal the dynamic range and diverse mechanisms of G-protein-coupled receptor activation. Nature 2016, 535, 448-452. [CrossRef] [PubMed]

164. Ferasin, L.; Gabai, G.; Beattie, J.; Bono, G.; Holder, A.T. Enhancement of FSH bioactivity in vivo using site-specific antisera. J. Endocrinol. 1997, 152, 355-363. [CrossRef] [PubMed]

165. Glencross, R.G.; Lovell, R.D.; Holder, A.T. Monoclonal antibody enhancement of FSH-induced uterine growth in snell dwarf mice. J. Endocrinol. 1993, 136, R5-R7. [CrossRef] [PubMed]

166. Licht, P.; Gallo, A.B.; Aggarwal, B.B.; Farmer, S.W.; Castelino, J.B.; Papkoff, H. Biological and binding activities of equine pituitary gonadotrophins and pregnant mare serum gonadotrophin. J. Endocrinol. 1979, 83, 311-322. [CrossRef]

167. Guillou, F.; Combarnous, Y. Purification of equine gonadotropins and comparative study of their acid-dissociation and receptor-binding specificity. Biochim. Biophys. Acta 1983, 755, 229-236. [CrossRef]

168. Combarnous, Y.; Guillou, F.; Martinat, N. Comparison of in vitro follicle-stimulating hormone (FSH) activity of equine gonadotropins (luteinizing hormone, $\mathrm{FSH}$, and chorionic gonadotropin) in male and female rats. Endocrinology 1984, 115, 1821-1827. [CrossRef]

169. Hervé, V.; Roy, F.; Bertin, J.; Guillou, F.; Maurel, M.-C. Antiequine chorionic gonadotropin (eCG) antibodies generated in goats treated with eCG for the induction of ovulation modulate the luteinizing hormone and follicle-stimulating hormone bioactivities of eCG differently. Endocrinology 2004, 145, 294-303. [CrossRef]

170. Wehbi, V.; Decourtye, J.; Piketty, V.; Durand, G.; Reiter, E.; Maurel, M.C. Selective modulation of follicle-stimulating hormone signaling pathways with enhancing equine chorionic gonadotropin/antibody immune complexes. Endocrinology 2010, 151, 2788-2799. [CrossRef]

171. Agrawal, G.; Dighe, R.R. Critical involvement of the hinge region of the follicle-stimulating hormone receptor in the activation of the receptor. J. Biol. Chem. 2009, 284, 2636-2647. [CrossRef]

172. Crepin, R.; Veggiani, G.; Djender, S.; Beugnet, A.; Planeix, F.; Pichon, C.; Moutel, S.; Amigorena, S.; Perez, F.; Ghinea, N.; et al. Whole-cell biopanning with a synthetic phage display library of nanobodies enabled the recovery of follicle-stimulating hormone receptor inhibitors. Biochem. Biophys. Res. Commun. 2017, 493, 1567-1572. [CrossRef] [PubMed]

173. Zhang, Y.L.; Guo, K.P.; Ji, S.Y.; Liu, X.M.; Wang, P.; Wu, J.; Gao, L.; Jiang, T.Q.; Xu, T.; Fan, H.Y. Development and characterization of a novel long-acting recombinant follicle stimulating hormone agonist by fusing Fc to an FSH- $\beta$ subunit. Hum. Reprod. 2016, 31, 169-182. [CrossRef]

174. Carr, R.; Benovic, J.L. From biased signalling to polypharmacology: Unlocking unique intracellular signalling using pepducins. Biochem. Soc. Trans. 2016, 44, 555-561. [CrossRef] [PubMed] 
175. Kahsai, A.W.; Wisler, J.W.; Lee, J.; Ahn, S.; Cahill, T.J., III; Dennison, S.M.; Staus, D.P.; Thomsen, A.R.B.; Anasti, K.M.; Pani, B.; et al. Conformationally selective RNA aptamers allosterically modulate the ß2-adrenoceptor. Nat. Chem. Biol. 2016, 12, 709-716. [CrossRef] [PubMed]

176. Zambrano, F.; Carrau, T.; Gärtner, U.; Seipp, A.; Taubert, A.; Felmer, R.; Sanchez, R.; Hermosilla, C. Leukocytes coincubated with human sperm trigger classic neutrophil extracellular traps formation, reducing sperm motility. Fertil. Steril. 2016, 106, 1053-1060.e1. [CrossRef]

(C) 2020 by the authors. Licensee MDPI, Basel, Switzerland. This article is an open access article distributed under the terms and conditions of the Creative Commons Attribution (CC BY) license (http://creativecommons.org/licenses/by/4.0/). 